\title{
Why Care About Caregivers? Using Communitarian Theory to Justify Protection of "Real" Workers
}

\author{
Nicole Buonocore Porter*
}

\section{INTRODUCTION}

Scholars, policy makers, the media, ${ }^{1}$ and the public have spent years discussing a single problem ${ }^{2}$ with many names: work/family conflict, ${ }^{3}$ the maternal wall, ${ }^{4}$ caregiver discrimination, family responsibilities

\footnotetext{
* Associate Professor of Law, University of Toledo College of Law. I wish to thank Professors Joseph Slater and Rebecca Zietlow for their valuable feedback. I am also grateful for the feedback I received when I presented this Article at the Third Annual Labor \& Employment Colloquium in San Diego, California, in October 2008; the Ohio Legal Scholars Workshop in January 2009; as well as the feedback received from the faculties of the University of Toledo College of Law and the University of Indiana-Indianapolis; where I presented the Article at workshops. Matthew Kizaur provided valuable research and editing support. I am grateful for the summer research grant provided by the College of Law, which made this Article possible.

1. See, e.g., Kathy Lauer-Williams, Mom Fights for Law Against Maternal Profiling, Morning CALl, Mar. 17, 2008, at A1; Mary Seguin, Editorial, The "Mommy Track" Myth, PROVIDENCE J., July 28, 2007, available at http://www.projo.com/opinion/contributors /content/CT_seguin28_07-28-07_M45VR3J.11d5989.html; Ian Shapira, Bringing Up Babies, and Defying the Norm, WASH. PosT, Jan. 15, 2008, at A01; Suzy Welch, Can You Work This Weekend?, O MAGAZINE, Mar. 2008, at 91.

2. For a discussion of the problem's prevalence, see Joan C. Williams, The U.S. Equal Employment Opportunity Comm'n, Statement at the Meeting of April 17, 2007, Washington D.C. on Perspectives on Work/Family Balance and the Federal Equal Employment Opportunity Laws (Apr. 17, 2007) (transcript available at http://www.eeoc.gov/abouteeoc/meetings/4-1707/williams.html) (stating that more than 100 articles have been published about family responsibilities discrimination (FRD) and that there has been a 400 percent increase in FRD cases over the past decade, with a higher success rate compared to other types of employment discrimination cases).

3. See generally Laura T. Kessler, Keeping Discrimination Theory Front and Center in the Discourse over Work and Family Conflict, 34 PEPP. L. REV. 313 (2007).

4. Professor Joan Williams coined the term "maternal wall," JOAN WILLIAMS, UNBENDING Gender: Why FAmily AND Work CONFLict and What to Do ABout It 69-70 (2000) [hereinafter WILLIAMS, UNBENDING GENDER], which I find very apt, although under-inclusive. In more recent articles, Williams has referred to this problem as "family responsibilities discrimination," to recognize the fact that the problem affects not just women, but also men, and to recognize the fact that some caregivers are caring for elderly parents or other family members. Joan C. Williams \& Stephanie Bornstein, Caregivers in the Courtroom: The Growing Trend of Family Responsibilities Discrimination, 41 U.S.F. L. REV. 171, 171 (2006).
} 
discrimination, ${ }^{5}$ and the attachment gap, ${ }^{6}$ among others. I call it the "caregiver conundrum,"7 referring to the fact that this topic has puzzled me and others for years. What is the caregiver conundrum? Simply put, it is the difficulty caregivers ${ }^{8}$ face when trying to balance their caregiving responsibilities with their work responsibilities. Caregivers face conflicts both at home and at work when work responsibilities clash with responsibilities at home. ${ }^{9}$ In many cases, these conflicts create serious hardships on the caregivers and their loved ones.

Finding a solution to this pressing problem is puzzling because courts and scholars disagree on the scope of the problem. Thus far, courts only protect employees who experience caregiver discrimination because the employer incorrectly assumes the employee will not meet the workplace requirements. ${ }^{10}$ In other words, courts only protect "ideal workers," 11 who never miss work because of caregiving responsibilities. But for many women ${ }^{12}$ who cannot conscientiously delegate all of their

5. See Williams \& Bornstein, supra note 4.

6. Laura Kessler, The Attachment Gap: Employment Discrimination Law, Women's Cultural Caregiving, and the Limits of Economic and Liberal Theory, 34 U. MICH. J.L. REFORM 371, 371 (2001).

7. Conundrum is defined as: "anything that puzzles." RANDOM HOUSE UNABRIDGED DICTIONARY 443 (2d ed. 1993).

8. For purposes of this Article, the term caregiver refers to either parents or those caring for their elderly, sick, or disabled relatives.

9. See Debbie N. Kaminer, The Work-Family Conflict: Developing a Model of Parental Accommodation in the Workplace, 54 AM. U. L. REV. 305, 306 (2004) (discussing a study where thirty percent of adults had experienced a conflict the previous week).

10. See Phillips v. Martin Marietta Corp., 400 U.S. 542, 544 (1971). For additional information, see discussion infra Part III.A.

11. I again thank Professor Williams for this term. WILLIAMS, UNBENDING GENDER, supra note 4, at 6, 64. I use this term frequently to describe what most employers expect to have-employees who are available full-time and overtime fifty weeks a year. Id. I do not mean to suggest that employers are reasonable in their expectations for ideal workers. I also do not think many employees are truly "ideal" in the ordinary sense of the word. Many employees might work fulltime and overtime and yet spend some of their time at work surfing the Internet or otherwise wasting time. I recognize this term's limitations but continue to use it because it is widely accepted and used in this context. Professor Michelle Travis refers to a "full-time, face-time norm," which I also find very apt. See Michelle A. Travis, Recapturing the Transformative Potential of Employment Discrimination Law, 62 WASH. \& LEE L. REV. 3, 6 (2005) [hereinafter Travis, Recapturing the Transformative Potential] (describing a set of default organizational preferences that many employers have for designing the workplace around full-time positions, requiring unlimited hours or rigid work schedules); Michelle A. Travis, The Full-Time, Face-Time Norm: Lessons from the United Kingdom, 10 EMPLOYEE RTS. \& EMP. POL'Y J. 257, 258 (2006) [hereinafter Travis, The FullTime, Face-Time Norm] (same).

12. While I intend the term caregiver to be gender neutral, I sometimes refer to "women" and "mothers" to recognize the reality that it is mostly women who suffer from this conundrum, while men are sometimes the primary caregivers of their children. See EQUAL EMP. OPPORTUNITY COMM'N, NOTICE, ENFORCEMENT GUIDANCE: UnlaWFul TREATMENT OF WORKERS WiTH CAREGIVING RESPONSIBILITIES 4 (2007) [hereinafter EEOC CAREGIVER GUIDANCE], available at http://www.eeoc.gov/policy/docs/caregiving.html (discussing men in caregiving roles today), it is 
childcare, even if they have the financial means to do so, and for other women who do not have the means to delegate all or most of their childcare responsibilities, ${ }^{13}$ occasionally their work suffers because the laws of physics prevent them from being in two places at once. ${ }^{14}$ These caregivers are what I call "real workers." Real workers are the caregivers who get the job done, probably very efficiently, but either do not put in as many hours as their non-caregiver counterparts, or violate their employers' attendance policies because they have children or other family members who need care. These are the parents to whom "life happens," and they are left juggling without a lesson, which inevitably leads to one or more balls falling to the ground.

Who are these real workers? They are single moms, ${ }^{15}$ married moms, moms with enough money for good daycare, moms with barely enough money for substandard daycare, ${ }^{16}$ and even some dads. ${ }^{17}$ They come in all races, religions, and sexual orientations. ${ }^{18}$ These are the women who feel the wage gap most severely ${ }^{19}$ and often feel like quitting. ${ }^{20}$ They are the caregivers who feel guilty for being just "good

still true that women are overwhelmingly the primary caregivers in their children's lives, even if they work full-time. WiLliams, UNBENDING GENDER, supra note 4, at 2; Williams \& Bornstein, supra note 4 , at 174 .

13. See Heather S. Dixon, National Daycare: A Necessary Precursor to Gender Equality with Newfound Promise for Success, 36 COLUM. HUM. RTS. L. REV. 561, 564-65 (2005) (arguing that many Americans do not have enough money for daycare).

14. See Williams, supra note 2 (referring to a study that found that caregiving responsibilities now interrupt one out of every three work days).

15. See EEOC CAREgiver GuidAnCE, supra note 12 (discussing the more profound effect of caregiving responsibilities on single mothers).

16. See Williams, supra note 2 (noting that many of the plaintiffs experiencing family responsibilities discrimination are caregivers in lower-income jobs, "for whom 'opting out' is not an option, and losing their jobs means living in poverty").

17. See Joan C. Williams \& Stephanie Bornstein, The Evolution of "FReD": Family Responsibilities Discrimination and Developments in the Law of Stereotyping and Implicit Bias, 59 HASTINGS L. J. 1311, 1318-21 (2008) (discussing the diversity of plaintiffs who bring family responsibilities discrimination claims, who vary by occupation, class, race or gender).

18. See EEOC CAREGIVER GUIDANCE, supra note 12 (noting that caregiving responsibilities can more dramatically affect women of color because they are more likely to be employed while raising young children, to be single, and to be caring for other relatives); Nancy E. Dowd, Bringing the Margin to the Center: Comprehensive Strategies for Work/Family Policies, 73 U. CIN. L. REV. 433, 434 (2004) (stating that we should be concerned with everyone - all classes and races-when discussing work and life balance issues).

19. See Joan C. Williams \& Nancy Segal, Beyond the Maternal Wall: Relief for Family Caregivers Who Are Discriminated Against on the Job, 26 HARV. WOMEN's L.J. 77, 77-78 (2003) ("Sociological studies show that motherhood accounts for an increasing proportion of the wage gap between men and women. While the wages of young women without children are close to those of men, mothers' wages are only sixty percent of those of fathers." (citations omitted)); see also Michael Selmi, The Work-Family Conflict: An Essay on Employers, Men and Responsibility, 4 U. ST. THOMAS L.J. 573, 581 (2007) (discussing the problem women face).

20. Gillian Lester, A Defense of Paid Family Leave, 28 HARV. J.L. \& GENDER 1, 21 (2005). In 
enough" and frequently allow themselves to be marginalized through reduced hours or part-time work schedules because society has taught them that they are not worthy of equal wages. ${ }^{21}$ They are, after all, not ideal workers. These are the caregivers who deserve our attention and this Article is devoted to including them in the efforts to remedy the caregiver conundrum. This Article does not discuss the logistics of solving the caregiver conundrum; that effort is left for another day. Instead, this Article tackles theory first, providing the theoretical justification for the eventual reform piece of the puzzle. Specifically, this Article proposes using a new theoretical framework, communitarian theory, ${ }^{22}$ to justify the protection of real workers.

Thus far, finding solutions to protect real workers has proven puzzling. Scholars recognize that caregivers who are not ideal workers need benefits and protections that are not offered by current employment laws. ${ }^{23}$ Accordingly, many of these scholars have suggested reforms to help real workers succeed in balancing work and life. ${ }^{24}$ However, many of these suggested reforms suffer from two challenges. First, most of the reforms are piecemeal. They only take care of some of the problems for some of the caregivers. They either focus on high-income professional women who want to work fewer hours, ignoring lower-income workers who need to work full-time and overtime, ${ }^{25}$ or they propose measures aimed at getting all women to work more hours, thereby ignoring caregivers who can afford to spend more time doing the valuable work of caring for their loved ones. ${ }^{26}$

fact, many women do quit because of the difficulty in balancing work and family. $I d$. at $21 \mathrm{n} .82$.

21. See Dixon, supra note 13, at 658 (stating that women "often even view themselves as unworthy employees, feeling they are short-changing their employers because of their family responsibilities"); cf. Travis, Recapturing the Transformative Potential, supra note 11, at 20 (discussing the system justification theory and how women rationalize their lower wages by believing that they are not worth the higher salaries given to men).

22. See infra Part IV.A.1.

23. See, e.g., Kessler, supra note 6, at 375 (recognizing that our current laws are not good enough to provide for the most common employment needs of caregivers)

24. See infra Part V.

25. See Michael Selmi \& Naomi Cahn, Women in the Workplace: Which Women, Which Agenda, 13 DUKE J. GENDER L. \& POL'Y 7, 19-23 (2006) (discussing proposals that emphasize women working fewer hours or getting more workplace flexibility).

26. Primarily, scholars fall into two basic groups-those who favor more choices for working mothers to balance work and family and those who favor more workplace equality for women and therefore believe women should be working more. Rachel Arnow-Richman, Accommodation Subverted: The Future of Work/Family Initiatives in a "Me, Inc." World, 12 TEX. J. WOMEN \& L. 345, 395-96 (2003); Selmi, supra note 19, at 573-74. Compare Kaminer, supra note 9, at 308-09 (proposing an accommodation model based on section 701(j) of Title VII of the 1964 Civil Rights Act), Christine A. Littleton, Reconstructing Sexual Equality, 75 CAL. L. REv. 1279, 1295-96 (1987) (discussing scholars who favor accommodation), and Peggie R. Smith, Parental-Status Employment Discrimination: A Wrong in Need of a Right?, 35 U. Mich. J.L. ReForm 569, 598-99 (2002) 
The other limitation of many reform proposals is that they suffer from what I call "special-treatment stigma." Special-treatment stigma occurs when employers are unwilling to hire or promote employees who need special benefits or accommodations in the workplace because of the real or perceived costs of providing such accommodations. ${ }^{27}$ Because most caregivers are women, any suggested reforms that help caregivers may have the perverse effect of causing employers to hire or promote fewer women. ${ }^{28}$ Special-treatment stigma also manifests itself in the resentment of other employees over the perceived special treatment given to caregivers. ${ }^{29}$

The solution to the first limitation-piecemeal reforms - is to devise reform that is broad enough to protect all workers, not just ideal workers and not just one subset of the caregiving population. But doing so is likely to be met with substantial resistance-both apathy and resentment - by employers, non-caregivers, and the public. For reasons discussed below, current theoretical frameworks have proven unsuccessful in supporting efforts at broad reform and combating special-treatment stigma. ${ }^{30}$ Thus, we need a new theoretical framework to justify broad coverage to protect all working caregivers and to respond to the special-treatment concern. ${ }^{31}$ Communitarian theory supplies the necessary justification.

Communitarian theory's emphasis on the priority of responsibilities over rights, the importance of raising children well, and working together to reach a common goal provides the needed justification for supporting broad reform efforts aimed at ending the caregiver conundrum for all workers-both real and ideal. ${ }^{32}$

(discussing the need to turn away from traditional anti-discrimination principles in the context of parental-status employment discrimination), with Dixon, supra note 13, at 565 (calling for a system of national daycare as an important step in helping women achieve gender equality), Lester, supra note 20, at 1-5 (advocating for paid family leave as a way to help equalize male and female contributions to both work and family caregiving), and Selmi, supra note 19, at 576 (arguing for workplace equality for women that does not entail more time away from work).

27. See infra Part IV.B.

28. See infra Part IV.B.

29. See infra Part IV.B.

30. See infra Part IV.A.1, IV.B.1.

31. I do not mean to suggest that communitarian theory is new. To my knowledge, however, this is the first Article to suggest using the communitarian theory to inform the debate regarding caregiver discrimination. Other scholars have recognized the importance of caregiving and the problems with the liberal ideal of autonomy and equality. See, e.g., Kessler, supra note 6, at 430 44. However, this is the first Article to take a systematic approach to applying the communitarian theory to the problem of caregiver discrimination.

32. See infra Part IV.A.2, IV.B.2. 
This Article will proceed in four parts. Part II will discuss the challenges facing real workers, including those who want more time with their family without sacrificing their careers and those who need to work full-time to make ends meet. Part II will also discuss discrimination based on stereotyping that affects even ideal workers. ${ }^{33}$ Part III will then discuss how and why the current law does not adequately protect those caregivers who are not meeting the ideal-worker norm.

Part IV presents this Article's thesis. It begins by arguing that we should support all caregivers, regardless of the choices they make-or are forced to make-in balancing work and family. Accordingly, any efforts at reform should include the protection of real workers and not just ideal workers. This part will discuss the two primary obstacles to protecting real workers-society's emphasis on the choices parents make $^{34}$ and the stigma that surrounds caregivers who receive special accommodations in the workplace. ${ }^{35}$ I first describe why current theories have been unsuccessful in remedying caregiver discrimination for real workers. Then I discuss how a shift to communitarian theory helps to hurdle both of these obstacles. Specifically, communitarian theory helps us understand that parenting is not merely a choice-it is a responsibility that benefits all of society. Part IV then discusses how communitarian theory addresses special-treatment stigma, by moving away from a focus on the conflict between men and women or caregivers and noncaregivers, and putting emphasis instead on working toward a common goal-raising the next generation, or caring for the prior generation, successfully.

Part V will briefly discuss where to go from here; broadly addressing which reforms will be needed to solve the caregiver conundrum for all working caregivers, including real workers. While reform must be comprehensive, this part cannot be. Instead, it will briefly discuss a sampling of some of the reforms that have been suggested by other scholars. Part V will then apply the communitarian framework to one specific reform to show how the theory provides justification for it. Finally, this part will briefly respond to anticipated criticisms of any eventual reform - that it will be too costly and burdensome on employers

33. While it is not my primary purpose to protect ideal workers - I believe they are already protected by current Title VII jurisprudence-I include a discussion of them to demonstrate the full scope of the caregiver conundrum.

34. Kessler, supra note 6, at 372 (discussing the rhetoric of choice surrounding women's caregiving).

35. See infra Part IV.B. 
and that employers will unduly burden non-caregiving co-employees by passing some of the costs on to them.

\section{DESCRIBING THE CAREGIVER CONUNDRUM}

The caregiver conundrum affects caregivers in three primary ways. First, some caregivers need and want more time with their families and are either unable to obtain that balance or are only able to obtain it through marginalizing their careers. Second, parents and other caregivers in lower-income brackets might also enjoy more time with their children, but are financially unable to work less or take time off for caregiving needs. These caregivers need more financial support in addition to time off for necessary caregiving. ${ }^{36}$ Finally, some caregivers experience the caregiver conundrum because, even though they are performing as ideal workers, their employers assume they are not. Cognitive bias and stereotyping are responsible for this type of discrimination. This part will discuss each of these in turn.

\section{A. Caregivers Who Need More Time}

For many caregiving employees, especially those in the middle to upper income brackets and professional careers, the primary impediment to balancing work and family is time, or the lack thereof. ${ }^{37}$ The normal full-time and overtime work schedule of many jobs makes it difficult for many workers to meet the caregiving needs of their loved ones. ${ }^{38}$ While there have been small legal measures aimed at alleviating this time crunch, ${ }^{39}$ such reforms only help caregivers in need of time off for a few enumerated reasons. ${ }^{40}$ What many caregivers need is the ability to take time off for school conferences; for doctor, dentist, and other appointments for their children or other loved ones in their care; and for recitals, classes and sporting events. ${ }^{41}$ Some parents simply want to work fewer hours so they can be home more, regardless of the age of

\footnotetext{
36. Sometimes, these caregivers are left making an impossible choice of keeping their jobs or providing necessary care for their loved ones.

37. WiLliams, UNBENDING GENDER, supra note 4, at 16.

38. Id.

39. See, e.g., Family and Medical Leave Act (FMLA) of 1993, 29 U.S.C. $\S \S 2601-2654$ (2006). The FMLA is discussed in Part III.

40. 29 U.S.C. $\S 2612(a)(1)$.

41. Peggie Smith, Accommodating Routine Parental Obligations in an Era of Work-Family Conflict: Lessons from Religious Accommodations, 2001 WIS. L. REV. 1443, 1452 (2001).
} 
their children. ${ }^{42}$ Many workplaces, however, do not allow this type of flexibility. ${ }^{43}$ Prevailing workplace practices remain firmly anchored to an ideal-worker norm that embodies the traditional life patterns of men. ${ }^{44}$ It is assumed that this ideal worker takes no time off for childbearing, has no daytime child rearing or other caregiving responsibilities, and is available full-time and for overtime on short notice. ${ }^{45}$ Several workplace policies exemplify the time crunch experienced by working caregivers who are not ideal workers.

The first of these are strict no-fault attendance policies that many employers adopt, especially for low-income, non-professional workplaces. ${ }^{46}$ Some employers allow as few as six to eight absences or partial-day absences in an entire year regardless of the reason. ${ }^{47}$ Furthermore, some employers allow for little or no time off for longer leaves of absence. ${ }^{48}$ These policies first affect women who are pregnant and give birth while employed. ${ }^{49}$ Assume a woman gets pregnant while working for an employer with a strict attendance policy. Even minor morning sickness or other minor complications make it very likely that she will accumulate six or more absences in a very short period of time. If she has worked for her employer for less than one year or her employer is not large enough to be covered by the Family Medical Leave Act (FMLA), ${ }^{50}$ the employer could fire her, ${ }^{51}$ and many employers do. ${ }^{52}$

42. Dowd, supra note 18, at 449-54 (noting that children need care not only while they are infants but well into adolescence); Williams, supra note 2 (same).

43. See National Snapshot: The Best vs. the Rest, Working Mother, Oct. 2007, at 78 (discussing a survey that states $58 \%$ of all companies allow flex-time, but only $20 \%$ allow job sharing, 33\% allow telecommuting (on a part time basis) and 38\% percent allow a compressed workweek); see also EEOC CAREGIVER GUIDANCE, supra note 12 (discussing the prevalence of employers' inflexible policies).

44. Williams \& Bornstein, supra note 4 , at 173-74

45. Id.

46. See Ellen Galinsky et Al., Families and Work Inst., National Study OF EMPLOYERS 12-13 (2008) (noting that most employers offer flexible work options only to a small portion of employees while a substantially smaller portion are willing to offer these benefits to all employees); see also id. at 13 (noting that only 32\% of employers let some employees change starting and ending times on a daily basis; only $3 \%$ of employers allow employees to work from home all or most working days; only $13 \%$ of employers let all or most employees work reduced hours; and only $45 \%$ of employers offer short periods of paid time off to attend to family needs).

47. EEOC CAREGIVER GUIDANCE, supra note 12.

48. Selmi \& Cahn, supra note 25, at 15 (stating that forty-nine percent of the workforce does not have any paid leave).

49. Travis, Recapturing the Transformative Potential, supra note 11, 40-41 (discussing a Seventh Circuit case, where the court considered an employer with a very rigid work schedule and a no-absence policy, finding no claim for a pregnant women).

50. See infra Part III.C for a discussion of FMLA requirements and limitations.

51. Selmi \& Cahn, supra note 25, at 22. ("Without the FMLA, those who have no access to sick leave could be terminated if they were to call in sick."). 
After pregnancy, caregiving causes absences for many different reasons. ${ }^{53}$ Absent FMLA protection, the employer's allowed absences have to cover sick days for the worker, sick days for the worker's children, appointments, conferences at school, performances at school, caring for a sick parent or partner, and so on. ${ }^{54}$ Many caregivers find it difficult, if not impossible, to meet their employers' very strict attendance policies, and hence, may find themselves making the impossibly unfair choice between keeping their jobs and doing what is required to care for their families. ${ }^{55}$ The number of women affected by stringent attendance policies is staggering, and most of these women are in the lowest income brackets. ${ }^{56}$ Some women are lucky enough to have a husband to help with caregiving needs, or a friend, family member, or neighbor who can help out when a child needs care. But many women do not have any help. ${ }^{57}$ Many women with caregiving responsibilities are single. ${ }^{58}$ And these days, women are less likely to have the support of family and friends nearby. ${ }^{59}$

Even in workplaces without strict attendance policies, high demands for "face time" make it difficult for caregivers to balance work and family. ${ }^{60}$ Some caregivers have jobs that could be performed, at least in

52. See Stout v. Baxter Healthcare Corp., 282 F.3d 856, 856 (5th Cir. 2002) (refusing plaintiff's disparate impact claim when she was fired after a miscarriage because of her employer's policy of firing employees with more than three absences during a 90-day probationary period); see also Pamela Gershuny, Family Values First When Federal Laws Collide: A Proposal to Create a Public Policy Exception to the Employment-At-Will Doctrine Based Upon Mandatory Parenting Duty, 21 WIS. WOMEN's L.J. 195, 202 (2006) (discussing cases where mother's were fired for staying home with their sick children); Ann O'Leary, How Family Leave Laws Left Out Low-Income Workers, 28 BERKELEY J. EMP. \& LAB. L. 1, 57 (2007) (noting that if a woman works for an employer exempted from the FMLA, she has no right to sick leave if her employer chooses not to offer it).

53. Arnow-Richman, supra note 26 (stating that caregivers are more likely to miss work).

54. Again, some of these absences are covered by the FMLA, but certainly not all of them. See infra Part III.

55. Gershuny, supra note 52, at 195 ("These parents are caught between the devil and the deep blue sea: they can leave their children alone or be fired.").

56. EEOC CAREGIVER GUIDANCE, supra note 12, at 1-5; see O'Leary, supra note 52 ("[F]or a low-wage working woman who has an ordinary breakdown in childcare or a child at home with the flu, the hardship will be magnified by her low income and lack of control over her work schedule.").

57. See EEOC CAREGIVER GUIDANCE, supra note 12 ("Family crises can sometimes lead to discipline or even discharge when a worker violates an employer policy in order to address caregiving responsibilities.").

58. Kessler, supra note 6, at 383-84 (stating that one-third of families with children under eighteen are single parent households).

59. See Dixon, supra note 13, at 572 (noting that grandmothers, aunts, and friends who have historically provided daycare are no longer able to); Gershuny, supra note 52, at 201 ("In a highly mobile society, the mothers, aunts, grandmothers, and other female relatives, once available for help, are often miles away.").

60. See generally Travis, Recapturing the Transformative Potential, supra note 11, at 15-17 (explaining the importance of face time in employee evaluations). 
part, at home but their employers require full-time hours at work. Other caregiving employees might be very productive and efficient but are valued primarily for the time spent at work. ${ }^{61}$ Many companies use facetime as a proxy for productivity and talent because they lack a system of formal evaluation or the evaluations are based on subjective criteria, like popularity. ${ }^{62}$ Thus, even for employees not constrained by strict attendance policies, the "full-time, face-time norm" ${ }^{63}$ makes it difficult for working caregivers to balance work and family.

The second workplace norm that makes it very difficult for caregivers to succeed in the workplace is required overtime. Studies indicate that "[n]inety-five percent of mothers aged twenty-five to fortyfour with school-aged children at home work less than fifty hours a week." ${ }^{64}$ Employers, especially in many of the professions, often require more than fifty hours per week, making it easy to see how most mothers cannot meet this ideal-worker norm. ${ }^{65}$ Because many women in these types of jobs are married to men in high-powered, high-demand careers, ${ }^{66}$ it is obvious how this overtime norm becomes very difficult for working parents. Even if the parents are wealthy enough to employ a full-time nanny, many mothers are uncomfortable delegating away most of the childcare. ${ }^{67}$ With even an average commute of thirty minutes each way, a fifty-hour-per-week schedule would have the parent separated from the children for eleven hours per day. ${ }^{68}$ It is easy to see how this type of schedule would be undesirable for most primary caregivers. Women who choose to not work overtime also pay a price, not in excessive time away from their children, but in career costs. ${ }^{69}$ Employees who do not meet the ideal-worker overtime norm will often receive lower, or no, bonuses or raises and will be passed up for promotion and advancement. ${ }^{70}$ This is especially true in occupations that

61. See id.

62. Id.

63. See generally Travis, The Full-Time, Face-Time Norm, supra note 11.

64. Williams \& Bornstein, supra note 4 , at 177 .

65. WILLIAMS, UNBENDING GENDER, supra note 4, at 2.

66. Id. at 71-72.

67. Id. at 124 .

68. See id. at 53. But see Selmi \& Cahn, supra note 25 , at 10 (stating that employees are not working this much and in fact, the average worker spends 9.2 hours away from home between work and commuting). Although these authors do note that college educated employees work more hours than the 9.2 average. $I d$. at 11 .

69. WiLLIAMS, UNBENDING GENDER, supra note 4, at 54 .

70. Id. at 59. Some women might even get fired for refusing to work overtime. In Upton v $J W P$ Businessland, the plaintiff, a divorced single mother, was fired after she informed her employer she would not be able to work the hours the employer required-8:15 a.m. until 10:00 p.m., Monday through Saturday - because of her parental responsibilities. 682 N.E.2d 1357, 1358 (Mass. 1997). 
rely on billable hours, including lawyers, accountants, and others. ${ }^{71}$ Therefore, the overtime norm is another way the caregiver conundrum manifests itself for working parents and other caregivers.

Finally, caregivers in some careers are disadvantaged because of expectations of travel or relocation, or both. ${ }^{72}$ Because working mothers are still overwhelmingly the primary caregivers of their children, frequent travel obligations for work put an increased strain on their families. ${ }^{73}$ Accordingly, many women avoid travel obligations, ${ }^{74}$ either because their spouses essentially forbid their travel, or they feel too guilty to leave their spouses and children fending for themselves. These days, many more jobs require travel, so a caregiver who is unwilling to travel or puts limitations on travel will likely find job and promotion opportunities limited. ${ }^{75}$ Similarly, many women are not in a position to relocate because of their spouse's career. While this trend is changing slightly, it is still the case that many more women leave their jobs, homes, and communities to follow their husbands than the reverse. ${ }^{76} \mathrm{~A}$ workplace that creates a norm of being willing and able to relocate in order to achieve success will inevitably discriminate against female caregivers. ${ }^{77}$ A recent example of this issue arose in Dukes $v$. Wal-Mart Stores, Inc., ${ }^{78}$ a class action lawsuit against Wal-Mart. One of the requirements for management promotions at Wal-Mart was the willingness to move around within the company to different geographical areas. $^{79}$ Because women are less able to move for their jobs, the plaintiffs challenged this neutral job requirement under a disparate-

71. See Holly English, Gender on Trial: Sexual Stereotypes and Work/Life BALANCE IN THE LEGAL WORKPLACE 197 (2003) (noting a survey of associate lawyers that showed they were willing to accept smaller salaries and bonuses if they could work fewer hours).

72. See Williams, supra note 2 (discussing cases where women were discriminated against based on such expectations).

73. Of course, many women with children are willing to travel and yet are presumed unwilling because of their caregiving responsibilities. See Williams \& Bornstein, supra note 4, at 177-78 (discussing a benevolent stereotyping case where an employer assumed a working mother would be unwilling to travel).

74. See Arnow-Richman, supra note 26, at 355 (stating that caregivers are sometimes unable to travel for work).

75. See Williams \& Segal, supra note 19, at 122 (citing testimony of an employee who said few women in the upper ranks of the organization have children due partly to the high travel demands).

76. See Travis, Recapturing the Transformative Potential, supra note 11, at 20 (discussing studies that indicate that most women provide support for their husbands' careers).

77. When I was in private practice, one employer evaluated employees based on a five-point scale, and only employees who were willing and able to relocate achieved five points.

78. 222 F.R.D. 137 (N.D. Cal. 2004), aff'd, 509 F.3d 1168 (9th Cir. 2009).

79. Williams \& Bornstein, supra note 4, at 183. 
impact theory. ${ }^{80}$ This lawsuit is further evidence of how a relocation norm contributes to the caregiver conundrum.

\section{B. Caregivers Who Need More Financial Support}

The caregiver conundrum is even more pronounced for lowerincome workers, including many single mothers. ${ }^{81}$ They often do not have the financial means for adequate, reliable daycare, ${ }^{82}$ which makes it more difficult for them to perform as ideal workers and to comply with their employers' stringent attendance policies. ${ }^{83}$ The lower-paying positions are also the least likely to offer any type of leave benefits, and these employees are much less likely to be entitled to FMLA leave. ${ }^{84}$ This is because either they work for employers that are too small to be covered by the statute or the employees have not worked for the employer long enough to be eligible for FMLA leave. ${ }^{85}$ Even if employees are entitled to FMLA leave, many cannot afford to take a leave of absence because these leaves are often unpaid. ${ }^{86}$

In addition to inadequate leave policies, many employees in the lower-income brackets are not working enough to make ends meet. ${ }^{87}$ Many of the suggested proposals to remedy caregiver discrimination involve allowing caregivers to work fewer hours. ${ }^{88}$ These proposals are not helpful to caregivers who are working in low-paying, part-time positions. These employees need better full-time jobs with better pay, benefits, and other types of financial support. ${ }^{89}$ Some of the suggested proposals to help these lower-income workers include: more protection

80. See id. (discussing Dukes v. Wal-Mart). For a discussion of the disparate-impact theory, see infra Part III.A.

81. See Selmi \& Cahn, supra note 25 , at 12 (noting a "sharp increase in the percentage of single mothers who are in the labor market"); see also EEOC CAREGIVER GUIDANCE, supra note 12, at 5 (stating that the work and family conflicts are felt most profoundly by lower-income workers). See generally O'Leary, supra note 52.

82. Dixon, supra note 13, at 572-73.

83. EEOC CAREGIVER GUIDANCE, supra note 12, at 5 (noting that many lower-income workers cannot afford childcare).

84. O'Leary, supra note 52 , at 7 (stating that $75 \%$ of lower-wage women do not have sick leave and $40 \%$ have no paid leave at all).

85. Id. at 7-8; see infra Part III.C.

86. The FMLA does not require paid leave, only unpaid leave, so it is in the employer's discretion whether to pay for such leave. Selmi, supra note 19, at 580; Selmi \& Cahn, supra note 25 , at 16 .

87. See Selmi \& Cahn, supra note 25 , at 12 (noting that many lower-income employees are unable to trade hours for salary).

88. Id. at 19 .

89. Id. 
for part-time employees, national daycare, longer school days and years, additional coverage of the FMLA, and paid sick days and leaves of absence. $^{90}$ The bottom line: narrowly-tailored, piecemeal reforms will not work to remedy the conundrum for all caregivers. Some employees need and want more flexible schedules or the ability to work reduced hours; some employees need to work more hours or need more paid leave or financial assistance with daycare costs; and some employees need something in the middle. Thus, this Article is aimed at using the communitarian theory to justify broad protection to include all caregivers who struggle to balance work and family the best they can. ${ }^{91}$

\section{Discrimination Based on Stereotypes}

Not all caregiving employees are harmed because of their inability to meet their employer's demands. Some employees, through supportive friends and family networks, or great nannies, manage to meet the idealworker norm. Yet these employees might also suffer from the caregiver conundrum when they are disadvantaged by their employers' stereotypical beliefs regarding their work performance and commitment. $^{92}$

One study reviewing the stereotypes involving family caregivers in the workplace compared women on two axes: "competence" and "warmth." Participants rated "“career women' as low in warmth but high in competence, similar to 'career men' and 'millionaires.",94 In contrast, "'housewives' were rated as high in warmth but low in competence, close to ... the 'blind,' 'disabled,' 'retarded,' and 'elderly.", 95 When a woman becomes a mother, she may find herself perceived more as "a low-competence caregiver rather than as a highcompetence business woman." "96 As an example, one female attorney reported that she was given paralegal-type work when she returned from maternity leave, even though, in her words, "[she] had a baby, not a lobotomy.",97

90. Id. at 18-19; see infra Part V.

91. See infra Part IV.

92. See O'Leary, supra note 52, at 60; Williams \& Segal, supra note 19, at 90. Furthermore, as stated earlier, even if caregivers are managing to perform as ideal workers, doing so often comes at a cost to either their families or their emotional well-being.

93. Williams \& Segal, supra note 19 , at 90.

94. Id.

95. Id.

96. Id.

97. Id. at 90-91 (quoting Deborah L. Rhodes, Myths of Meritocracy, 65 FordHAM L. REV. 585, 
In addition, women may be stereotyped by those trying to be helpful to the caregiving workers. ${ }^{98}$ This is known as "benevolent stereotyping." 99 For instance, some managers might not consider mothers for jobs that require travel or a great deal of overtime, and when challenged, they would defend such decisions as being thoughtful or considerate of the mothers' responsibilities. ${ }^{100}$ Consider the following example:

[A]fter a husband and wife who worked for the same employer had a baby, the wife was sent home at 5:30 P.M., with the solicitous sentiment that she should be at home with the child. In sharp contrast, the husband was given extra work and was expected to stay late. The additional work was meant to be helpful, for the husband now had a family to support. ${ }^{101}$

Regardless of whether the stereotyping is meant to be harmful or helpful, it deprives a woman of the power to make these decisions for herself. ${ }^{102}$

Lawsuits challenging this type of discrimination exemplify the severity of the problem. ${ }^{103}$ In one case, the plaintiff-mother testified that the vice-president of a company had repeatedly asked "how her husband was managing given she was not home to cook for him, how work was going in light of her new child, and whether she could perform her job effectively after having a second child." 104 The vice-president told her that he preferred "unmarried, childless women because they would give $150 \%$ to the job." 105

In another case, a vice-president told the plaintiff-mother that he "would not give her the promotion because she was married, pregnant,

$588(1996))$.

98. Id.; see Kathryn Abrams, Ideology \& Women's Choices, 24 GA. L. REV. 761, 782 (1990) (stating that "women feel pulled between an ideology of "neutrality," teaching them that they can be as good as their male counterparts and achieve the ideal career, and an "ideology of domesticity," teaching them that a self-centered career can and will take a toll on the lives of their family).

99. Joan C. Williams, Beyond the Glass Ceiling: The Maternal Wall as a Barrier to Gender Equality, 26 T. JEFFERSON L. REV. 1, 5-6 (2003).

100. Williams \& Segal, supra note 19, at 91.

101. Id. at 95-96 (citations omitted).

102. Id. at 95; see also EEOC CAREGIVER GUIDANCE, supra note 12, at 17-18 (describing a hypothetical where a boss assigns a new caregiver smaller accounts so she could better handle her new caregiving responsibilities).

103. I mention these cases to indicate the prevalence of managers using stereotypes to make employment decisions that negatively affect working caregivers. I do not mean to suggest that the law is inadequate to take care of these types of stereotyping cases; in fact, I assert the opposite. See infra Part III.A.

104. Williams \& Segal, supra note 19, at 125 (citing Santiago-Ramos v. Centennial P.R. Wireless Corp., 217 F.3d 46, 55-58 (1st Cir. 2000)).

105. Id. (quoting Santiago-Ramos, 217 F.3d at 51). 
and a mother and he believed she should stay at home caring for her family." 106 In yet another case, the plaintiff-caregiver "was told that she was not considered for a promotion because the new management position required extensive traveling, and it was assumed that she would not be interested because of her family obligations." 107 The senior vicepresident commented to the plaintiff "'about the incompetence and laziness of women who are also working mothers,' and also noted that women are not good planners, especially women with kids." 108 Another executive stated "that working mothers cannot be both good mothers and good workers, saying 'I don't see how you can do either job well.,"'109

Two recent cases further demonstrate how employers discriminate by making decisions based on stereotypical beliefs, rather than reality. In Back v. Hastings on Hudson Union Free School District, ${ }^{110}$ the plaintiff was a school psychologist who was told by her supervisors that it was not possible to do the job with little children at home. ${ }^{111}$ She was denied tenure based on the assumption that she would not continue to work hard once she obtained tenure. ${ }^{12}$ In another case, Lust v. Sealy, Inc., ${ }^{113}$ the plaintiff was an ambitious, successful salesperson who had repeatedly expressed her desire to be promoted. ${ }^{114}$ Nevertheless, her supervisor denied her promotion to a management position based on the belief that, because she had children, she would be unwilling to move. ${ }^{115}$ These types of cases exemplify the discrimination facing caregivers even when they are meeting the ideal-worker norm.

As is clear from the above discussion, the caregiver conundrum includes all of the employer norms, policies, and actions that disadvantage and discriminate against caregivers in the workplace - both real workers and ideal workers. The next part will discuss why current laws have proven inadequate in resolving the caregiver conundrum for real workers.

\footnotetext{
106. Id. at 126 (citing Moore v. Ala. State Univ., 980 F. Supp. 426, 431 (M.D. Ala. 1997)) "Moreover, [the vice-president] declared, looking at her pregnant belly: 'I was going to put you in charge of that office, but look at you now." Id. (quoting Moore, 980 F. Supp. at 431).

107. Id. at 127 (citing Trezza v. Hartford, Inc., No. 98 Civ. 2205, 1998 U.S. Dist. LEXIS 20206, at *3 (S.D.N.Y. Dec. 30, 1998))

108. Id. (citing Trezza, 1998 U.S. Dist. LEXIS 20206, at*5).

109. Id.

110. 365 F.3d 107 (2d Cir. 2004).

111. Id. at 114-15.

112. Id. at 115 .

113. 383 F.3d 580 (7th Cir. 2004).

114. Id. at 583 .

115. Id.
} 


\section{INADEQUACY OF CURRENT LAW}

No federal statute explicitly prohibits discrimination against working adults with caregiving responsibilities, ${ }^{116}$ and only a few states provide any explicit protections. ${ }^{117}$ While there may be several possible laws caregivers could use to challenge discrimination by their employers, ${ }^{118}$ arguably three main prohibitions are most often used: Title VII's prohibition against sex discrimination, the Pregnancy Discrimination Act, and the FMLA. ${ }^{119}$ Despite these legal protections, this part will demonstrate that these laws have done little to remedy the caregiver conundrum for real workers. ${ }^{120}$

\section{A. Title VII's Prohibition on Sex Discrimination}

Title VII of the Civil Rights Act of $1964^{121}$ states that it is unlawful to discriminate based on sex, as well as other protected categories, including race, color, religion, and national origin. ${ }^{122}$ The main difficulty with using Title VII to challenge employment decisions that disadvantage caregivers is that Title VII follows the equal-treatment doctrine of assimilation, whereby an employer must treat women and men alike only if the women are similarly situated to the men. ${ }^{123}$ Of course the problem, which is well recognized by many scholars, is that men and women are not alike. ${ }^{124}$ First and most obviously, only women can get pregnant, give birth, recover from childbirth, and possibly breastfeed their children. More importantly, however, men and women

116. EEOC CAREGIVER GUIDANCE, supra note 12, at 1.

117. Williams, supra note 99, at 2-3 (2003) (discussing statutes passed in Alaska and Washington, D.C.).

118. See, e.g., Williams \& Segal, supra note 19, at 122-23 (pointing to ten viable theories available for plaintiffs who are suffering from caregiver discrimination).

119. See EEOC CAREGIVER GuIDANCE, supra note 12, at 1, 10, 21-22 (describing common ways employers can be liable for caregiver discrimination).

120. Kessler, supra note 6, at 374-75 (discussing the inadequacy of the laws' ability to deal with women's cultural caregiving).

121. 42 U.S.C. $\S 2000 \mathrm{e}(2006)$.

122. Id. § 2000e-2(a) ("It shall be an unlawful employment practice for an employer... to discriminate against any individual with respect to his compensation, terms, conditions, or privileges of employment, because of such individual's race, color, religion, sex, or national origin . ...").

123. See Lucinda M. Finley, Transcending Equality Theory: A Way Out of the Maternity and the Workplace Debate, 86 Colum. L. REv. 1118, 1142, 1180 n.244 (1986) (explaining the equality doctrine); Littleton, supra note 26, at 1301-02 (1987) (stating that under some government models of equal treatment, "women merit equal treatment only so far as they can demonstrate that they are similar to men"). For more discussion of this topic, see infra Part IV.A.

124. Finley, supra note 123, at 1142-43; Littleton, supra note 26, at 1295. 
are not similarly situated when it comes to child rearing-women still perform the vast majority of child care and home-making duties. ${ }^{125}$ This fact often allows employers to get away with treating women differently, or worse, than men. Accordingly, many scholars have criticized Title VII as being an ineffective tool to address caregiver discrimination. ${ }^{126}$

While there has been an increase in the number of successful cases filed by caregivers, ${ }^{127}$ none of them involve caregivers who are real workers, i.e., caregivers who were not meeting the ideal-worker norm. While some scholars believe that hope exists on the litigation front, the cases often cited involve women who are meeting the ideal-worker norm. For instance, in Trezza v. Hartford, Inc., a woman lawyer sued her employer after she was repeatedly passed over for a promotion after having children, despite her history of excellent evaluations. ${ }^{128}$ Following the "sex-plus"129 precedent of Phillips v. Martin Marietta Corp. ${ }^{130}$ the district court held that the plaintiff had stated a prima facie case despite the fact that the person given the position was also a woman, as long as the other woman did not also share the same "plus" characteristic-here, having school-aged children. ${ }^{131}$ She also could prove sex-plus discrimination by comparing mothers to fathers, because the employer had considered fathers with school-aged children for the position. ${ }^{132}$ The other type of cases that are likely to be successful is

125. WILLIAMS, UNBENDING GENDER, supra note 4, at 48-54 (discussing how American women still feel pressured to stay home to take care of their children); Joanna L. Grossman, Job Security Without Equality: The Family and Medical Leave Act of 1983, 15 WASH. U. J.L. \& POL'Y 17, 53-54 (2004) (stating that the majority of people who take leave under FMLA policies are women); Williams \& Bornstein, supra note 4 , at 174 .

126. See, e.g., O'Leary, supra note 52, at 10 (stating that Title VII did nothing to accommodate women's and men's roles as caregivers); Williams \& Segal, supra note 19, at 78 n.10 (citing to other authors who believe that Title VII will be ineffective in remedying the problem of work and family conflict).

127. Williams, supra note 2 .

128. 1998 U.S. Dist. LEXIS 20206, at*2 (S.D.N.Y. Dec. 28, 1998). For an analysis of this case, see WILLIAMS, UNBENDING GENDER, supra note 4, at 101-02.

129. See generally Kessler, supra note 6, at 391-92, 401 (discussing the sex-plus theory and the Phillips v. Martin Marietta Corp. case). Kessler notes that the plaintiff in Phillips was successful because she challenged a policy that refused the hiring of any woman with preschool aged children but allowed the hiring of similarly situated men. Id. at 391-92. Kessler points out that courts have since interpreted the sex-plus claim to be actionable only if the "plus" is either "a fundamental right or an immutable characteristic." Id. at 392. Because having children was considered a fundamental right, the claim succeeded in Phillips. Id. at 400-01. However, because society believes a woman's caregiving role is freely chosen, there have been no reported cases where the plaintiff has argued or a court has found that a woman's status as a primary caregiver is an immutable characteristic. See id. at $401-02$.

130. 400 U.S. 542 (1971).

131. Trezza, 1998 U.S. Dist. LEXIS 20206, at**18-19.

132. Id. at **16-21. 
where managers make explicit comments that indicate that the reason for an adverse employment decision is the fact that a woman is about to have or already has children. ${ }^{133}$

For real caregivers, however, litigation is not as promising of an option. ${ }^{134}$ The reason these lawsuits fail depends upon the type of claim the woman brings. Assume a woman with children does not get promoted to the next level in her company. If she brings a disparatetreatment sex discrimination claim alleging that she was treated differently because of her caregiving responsibilities, ${ }^{135}$ the equaltreatment theory requires that she prove that the other employees who were promoted were similarly situated to her. ${ }^{136}$ However, if she is like many caregivers, she might not have worked as much as the employee who was promoted $;{ }^{137}$ therefore, she will struggle to meet her burden of proof.

Alternatively, if she brings a disparate-impact suit, her claim will similarly fail. A disparate-impact claim does not require that the plaintiff prove intentional discrimination, but rather that a characteristic-neutral policy or practice has a disproportionately negative effect on a particular class; here, the class is women. ${ }^{138}$ It is easy to see why disparate-impact claims could have great potential for challenging many of the workplace policies that make it difficult for caregivers to succeed. ${ }^{139}$ Because women bear a disproportionate burden of caregiving, stringent workplace policies regarding hours, attendance, and face-time will likely have a disproportionate effect on women. ${ }^{140}$ Accordingly, courts could use the disparate-impact theory to require employers to restructure existing workplace policies that disproportionately disadvantage women. ${ }^{141}$

133. See cases cited supra notes 104-09.

134. See generally Williams \& Segal, supra note 19, at 122-61 (discussing the outcomes of some of these types of cases).

135. This is called a "sex-plus" case. See Nicole Buonocore Porter, Sex Plus Age Discrimination: Protecting Older Workers, 81 DENV. U. L. REV. 79, 84-87 (2003) (discussing the history of the "sex-plus" discrimination doctrine).

136. Neuren v. Adduci, Mastriani, Meeks \& Schill, 43 F.3d 1507, 1514 (D.C. Cir. 1995). But see EEOC CAREGIVER GUIDANCE, supra note 12 , at 8 (stating that comparative evidence is not necessary).

137. WILLIAMS, UNBENDING GENDER, supra note 4, at 71

138. Id. at 105 .

139. Travis, Recapturing the Transformative Potential, supra note 11, at 37 ("Because this model focuses on inequitable results and does not require discriminatory intent by the employer, this model holds great potential for addressing aspects of women's inequality that stem from workplace organizational norms that create, retrench, or magnify women's disproportionate conflicts between work and family." (footnotes omitted)).

140. See id. at $37-39$.

141. See id. at 38 . 
However, when bringing these claims, women are likely to face three inter-related obstacles: (1) compiling the requisite statistics to show that the policy has a disparate impact on women; ${ }^{142}$ (2) identifying a specific policy or practice that caused the adverse employment decision; ${ }^{143}$ and (3) rebutting the employer's defense that the policy is justified by business necessity. ${ }^{144}$ Because long hours and overtime are the status quo at many companies, an attempt to change the status quo through litigation will be met with substantial resistance. ${ }^{145}$

The only cases that are likely to be successful under Title VII are those in which the mother performs as an ideal worker, but is nevertheless discriminated against because of stereotypical beliefs regarding women's traditional roles. ${ }^{146}$ As already discussed, the

142. See Williams, UnBending Gender, supra note 4, at 106; see also Kessler, supra note 6, at 415-16 (discussing the difficulty of proving the statistical disparities).

143. See Williams, UnBending Gender, supra note 4, at 106; Kessler, supra note 6, at 413 (noting that "[w]hile there are many identifiable, affirmative employer practices that serve to disadvantage women in the workplace, they are so entrenched, so accepted as the norm, that they are virtually invisible"); O'Leary, supra note 52, at 37; see also Dormeyer v. Comerica Bank-Illinois, 223 F.3d 579, 583-84 (7th Cir. 2000) (holding that a rigid work schedule and no-absence policy were not employment "practices" that could form the basis for a disparate-impact suit but were instead just requirements of the job). Professor Travis has argued that if judges were following a "transformative approach" to disparate-impact law under Title VII, they would distinguish a job's required tasks from the norms dictating when and where the tasks have to be completed. The courts could then see these norms as an employment practice subject to disparate-impact review. Travis, Recapturing the Transformative Potential, supra note 11, at 39. She notes, however, that most judges do not distinguish between actual job tasks and the norms regarding when and where work is to be performed, thereby defeating many disparate-impact claims. Id. ("Under this approach, a woman who experiences disproportionate conflicts between work and family as a result of a default workplace structure will have no cognizable target for her disparate impact claim, which requires the plaintiff to challenge a particular employment practice.").

144. WiLLIAMS, UNBENDING GENDER, supra note 4, at 106-07; Kessler, supra note 6, at 41617.

145. Travis, Recapturing the Transformative Potential, supra note 11, at 40-46 (discussing cases where disparate impact claims were not successful); see generally Kessler, supra note 6 . However, Professor Travis believes that the disparate-impact theory has some potential to be a useful tool to challenge employment practices that demand "full-time, face-time." Travis, Recapturing the Transformative Potential, supra note 11, at 83 (describing how the United Kingdom has had success challenging the full-time, face-time norm by using a theory similar to the disparate impact theory in the United States). Travis uses the United Kingdom model to demonstrate how it is possible to use the disparate-impact theory to challenge workplace policies that disproportionately disadvantage female caregivers. Id. Specifically, employees in the United Kingdom have had better success disputing that inflexible work policies are practices upon which a disparate impact suit can be brought, making it more difficult for employers to satisfy the business necessity defense. See id. Furthermore, Travis points out that disparate impact litigation can have positive effects, including changing institutional practices and prompting new legislation. Id. at 84 ; see also Williams \& Bornstein, supra note 4, at 186 (discussing the positive impact on institutional practices because of the threat of litigation).

146. See cases cited supra notes 103-114. See generally, EEOC CAREGIVER GUIDANCE, supra note 12; Joan C. Williams, Hibbs as a Federalism Case; Hibbs as a Maternal Wall Case, 73 U. CIN. L. REV. 365 (2004); Joan C. Williams, Litigating the Glass Ceiling and the Maternal Wall: Using 
caregiving responsibilities of many mothers prevent them from performing as ideal workers; therefore, litigation using Title VII is an unpromising option. ${ }^{147}$

Even though most scholars agree that Title VII is not the most effective tool for remedying caregiver discrimination, in May 2007, the Equal Employment Opportunity Commission (EEOC) issued Enforcement Guidance "regarding unlawful disparate treatment under the federal [Equal Employment Opportunity] laws of workers with caregiving responsibilities." ${ }^{148}$ The EEOC recognized that while there is no federal law prohibiting discrimination against caregivers per se, there are many circumstances where discrimination against caregivers might constitute unlawful discrimination based on protected characteristics under Title VII and other statutes. ${ }^{149}$

The EEOC Caregiver Guidance puts a great deal of emphasis on the stereotyping theory. For instance, many of the examples used by the EEOC are situations where the woman met her employer's expectations but was nevertheless treated unfavorably based on her employer's stereotypical belief that the woman's caregiving responsibilities would interfere with her performance. ${ }^{150}$ The EEOC emphasizes:

Although women actually do assume the bulk of caretaking responsibilities in most families and many women do curtail their work responsibilities when they become caregivers, Title VII does not permit employers to treat female workers less favorably merely on the genderbased assumption that a particular female worker will assume caretaking responsibilities or that a female worker's caretaking responsibilities will interfere with her work performance. ${ }^{15}$

However, consistent with the argument made above that only ideal workers are protected from discrimination, the EEOC notes that

Stereotyping and Cognitive Bias Evidence to Prove Gender Discrimination, 7 EMP. RTS. \& EMP. POL'Y J. 287 (2003).

147. See Kessler, supra note 6, at 407-08 (noting that plaintiffs are much less successful in cases where the plaintiffs' direct requests or their employment records reveal that they require an accommodation for family obligations). Kessler also states: "Before they are employed ... women [can] succeed[] in convincing courts that they can conform to the male-worker norm." Id. at 407. This is why the stereotypical cases succeed. But if the women fail at juggling it all, which inevitably many will, "[they] are penalized . . . for failing to conform or are disadvantaged vis-à-vis coworkers without caregiving responsibilities ... [and] Title VII and the ... formal equality [mode] on which it is based offers little protection." Id. at 407; see also Kaminer, supra note 9, at 328 (stating that Title VII provides little help for working mothers who need accomodation of their parenting obligations).

148. EEOC CAREGIVER GUIDANCE, supra note 12.

149. Id. at 1.

150. See generally id.

151. Id. at 11 . 
employment decisions based on the employee's actual performance, such as missing work because of childcare problems, do not violate Title VII, even if the employee's deficiencies result from caregiving responsibilities. $^{152}$ In other words, Title VII is most effective for challenging discrimination against caregivers who perform as ideal workers and not nearly as effective for challenging the institutional norms and practices that make it difficult for caregivers to perform as ideal workers. ${ }^{153}$

The EEOC also warns employers about unlawful stereotyping based on pregnancy, i.e., assuming an employee will not be capable of, or should not be performing certain tasks, or, alternatively, unlawfully refusing to modify duties for pregnant women. ${ }^{154}$ The EEOC further discusses the discrimination that hurts male caregivers, where employers have denied men the opportunity to be caregivers for their kids. ${ }^{155}$ Finally, the EEOC discusses discrimination against caregivers because of race and national origin, unlawful stereotyping based on association with an individual with a disability, hostile work environment claims, and retaliation claims. ${ }^{156}$ While the EEOC Guidance reveals the breadth of the types of discrimination caregivers might experience, as well as the legal claims they might bring, it does not address the types of institutional practices that make it very difficult for real workers to balance their caregiving responsibilities with their careers.

\section{B. The Pregnancy Discrimination Act}

As should be obvious from the title of this statute, which was an amendment to Title VII, the Pregnancy Discrimination Act (PDA) ${ }^{157}$

152. Id. at 16 .

153. Kaminer, supra note 9, at 329. For instance, Title VII is ineffective at challenging the norm of full-time work. There is no requirement under Title VII that employers allow employees to work part-time or reduced hours. Kessler, supra note 3, at 326. Title VII only requires that if an employer allows some caregivers to work part-time, it must not discriminate based on a protected classification when allowing part-time schedules. Williams, supra note 2.

154. EEOC CAREGIVER GUIDANCE, supra note 12, at 9-10, 22.

155. Id. at 24 .

156. Id. at 25-31.

157. The PDA reads:

The terms "because of sex" or "on the basis of sex" include, but are not limited to, because of or on the basis of pregnancy, childbirth, or related medical conditions; and women affected by pregnancy, childbirth, or related medical conditions shall be treated the same for all employment-related purposes, including receipt of benefits under fringe benefit programs, as other persons not so affected but similar in their ability or inability to work ....

42 U.S.C. $\S 2000 \mathrm{e}(\mathrm{k})(2006)$. 
only protects women who are pregnant or who are recovering from childbirth. $^{158}$ Furthermore, the PDA only requires employers to treat pregnant employees in the same way they would treat other employees similar in their ability or inability to work. ${ }^{159}$ In other words, a small employer who is not covered by the FMLA ${ }^{160}$ would not be required to provide any leave to pregnant employees as long as the employer similarly denies leave to an employee who, perhaps, breaks an arm or leg and cannot work for several weeks. ${ }^{161}$ Many women only get one or two weeks to recover from childbirth before they are expected to return to work, and, if a small employer chooses to, it can deny any leave at all for the birth of a woman's baby. ${ }^{162}$ While there have been some successful claims brought under the PDA, they tend to encompass situations where a woman gets pregnant and the employer fires or otherwise discriminates against her based on the stereotypical belief that she is no longer capable of being a productive employee or that she will not return to work after her maternity leave. ${ }^{163}$ Of course, since a great deal of the caregiver conundrum occurs after childbirth and before the child leaves for college, it is easy to see why the PDA does not provide adequate protection for caregivers. ${ }^{164}$

158. Id.; see also Kessler, supra note 6, at 397-99 (discussing the limitations of the PDAnamely, that it only covers the immediate physical benefits of pregnancy and childbirth and does not provide any remedy for a woman who needs to nurse her baby or needs time off to care for a newborn).

159. § 2000e(k); see also O'Leary, supra note 52, at 58-59 (stating that the PDA is not comprehensive because it only requires an employer to give leave benefits for pregnancy if it does so for other injuries).

160. See infra Part III.C.

161. See EEOC CAREGIVER GUIDANCE, supra note 12, at 11; see also Kessler, supra note 6, at 395 (stating that employers can treat pregnant employees as badly as they treat other non-pregnant employees).

162. This is true only if the employer would deny a leave of absence to other employees for other short-term illnesses or injuries. Indeed, "Employers can treat pregnant women as badly as they treat similarly affected but nonpregnant employees." Kessler, supra note 6, at 395 (quoting Troupe v. May Dep't Stores Co., 20 F.3d 734, 738 (7th Cir. 1994)).

163. See, e.g., Sheehan v. Donler Corp., 173 F.3d 1039, 1042-43 (7th Cir. 1999) (holding that a manager's comments of "[o]h my God, she's pregnant again" and "you're not coming back after this baby" were direct evidence of discrimination).

164. See Kessler, supra note 6, at 398; O'Leary, supra note 52, at 35-36 (noting that the PDA only applies to medical leave and not caregiving leave); Williams \& Bornstein, supra note 4, at 17273 (noting that many plaintiffs' attorneys initially filed suit under the Pregnancy Discrimination Act but these lawsuits were unsuccessful because the PDA does not protect new mothers). But see Susan E. Huhta, Elizabeth S. Westfall, \& Joan C. Williams, Looking Forward and Back: Using the Pregnancy Discrimination Act and Discriminatory Gender/Pregnancy Stereotyping to Challenge Discrimination Against New Mothers, 7 EMP. RTS. \& EMP. POL'Y J. 303, 304 (2003) (arguing that the PDA can be used to challenge discriminatory decisions against new mothers based on past pregnancies). 


\section{The Family and Medical Leave Act}

Enacted in 1993, the FMLA ${ }^{165}$ was thought to be a major benefit for working caregivers. Reports differ regarding the impetus for passing the FMLA. Some believe the gender neutrality of the statute (allowing both men and women to take caregiving leave) was necessary in order to ensure women's equality in the workplace by resolving the stigma associated with only allowing women to take such leaves. ${ }^{166}$ However, despite the neutrality of the law, others believe that the need to accommodate motherhood was the primary force behind the passage of the statute. ${ }^{167}$ Despite the divergence of opinions regarding how and why the FMLA was passed, most agree that the FMLA has provided only limited benefits to a limited group of workers. ${ }^{168}$

First of all, only employers with fifty or more employees within a seventy-five mile radius are covered by the FMLA. ${ }^{169}$ This requirement has a disproportionate effect on lower-income women who are more likely to be employed by small employers that are not required to provide any leave under the FMLA. ${ }^{170}$ Second, the FMLA defines eligible employees to include only those who have worked for more than one year for the company and have worked 1,250 or more hours in the past twelve months. "These conditions, taken together, effectively limit the Act's application to a minority of women workers, since women are more likely than men to work for small businesses, to work part-time, to work in occupations with little job security, and to interrupt their careers due to family responsibilities."

165. 29 U.S.C. $\S \S 2601-2654$ (2006).

166. Grossman, supra note 125, at 44 (2004); Kessler, supra note 6, at 419; see also O'Leary, supra note 52, at 40 (discussing the history of the FMLA and the concern regarding how it was classified - an accommodation statute was viewed negatively because of fear that it would make women more expensive to hire).

167. Grossman, supra note 125 , at 43 (discussing the emphasis during the FMLA hearings on the importance of mother-baby bonding).

168. Gershuny, supra note 52, at 201 (noting that other scholars have pointed to the inadequacy of the FMLA in resolving the majority of conflicts between child-rearing and work). Some state laws provide better protection and benefits than the FMLA, but the problems mentioned here still exist.

169. $§ 2611(4)(\mathrm{A})$.

170. Selmi \& Cahn, supra note 25, at 22; see also GALINSKY ET AL., supra note 46, at 19 (noting that it is usually large employers who are willing to provide benefits that cost money, such as paid leave); O'Leary, supra note 52, at 43 (noting that more than one half of low-wage workers are employed by small employers).

171. $\S 2611(2)(\mathrm{A})$.

172. Kessler, supra note 6, at 422 . 
either work for employers not covered by the FMLA or are themselves not eligible for FMLA leave. ${ }^{173}$

The FMLA's inadequacies are even more pronounced for lowerincome workers. One-third of single parents and low-income workers have been employed for less than one year and are therefore not covered by the Act. ${ }^{174}$ Because of all of the limitations mentioned above, the vast majority of lower-income employees are not covered by the FMLA. ${ }^{175}$ Another problem with the statute is that it only provides for unpaid leave, not paid leave. ${ }^{176}$ Many women who need maternity leave or leave to care for a sick child cannot afford to take it because they cannot afford to live without their income. ${ }^{177}$ Thus, it is easy to see that this statute, which certainly was a step in the right direction, nevertheless offers little assistance to lower-income workers. ${ }^{178}$

A further limitation of the FMLA is that it only provides leave for certain enumerated reasons, including:

(A) Because of the birth of a son or daughter of the employee and in order to care for such son or daughter.

(B) Because of the placement of a son or daughter with the employee for adoption or foster care.

(C) In order to care for the spouse, or a son, daughter, or parent, of the employee, if such spouse, son, daughter, or parent has a serious health condition.

(D) Because of a serious health condition that makes the employee unable to perform the functions of the position of such employee.

173. Grossman, supra note 125 , at 37 (stating that almost forty percent of employees are either ineligible or employed by an employer who is not large enough to be a covered entity under the FMLA). To make matters worse, one study indicates that eighteen to twenty-one percent of all employers who are covered under the FMLA do not comply with it. GALINSKY ET AL., supra note 46 , at 17 .

174. O'Leary, supra note 52, at 43-45.

175. Id. at 45 (explaining that "restrictions on employer and employee coverage disproportionately fall on the low-wage workforce").

176. § 2612(c).

177. See O'Leary, supra note 52, at 45 (stating that seventy-five percent of employees reported not being able to afford to take leave); Selmi, supra note 19, at 580 (emphasizing the problems with the lack of paid sick leave); Selmi \& Cahn, supra note 25, at 16 (stating that in results from two surveys of reasons for not taking leave, "by far the lartest category ... was an inability to afford to leave").

178. Gershuny, supra note 52, at 202 (noting that lower-income parents are more likely to be fired when they miss work for childcare reasons than higher-income parents).

179. $§ 2612(a)(1)$. 
The FMLA offers "no protection for the types of routine childcare obligations and contingencies that most commonly conflict with work requirements." ${ }^{180}$ Accordingly, the FMLA is an incomplete solution. ${ }^{181}$

Finally, despite the gender-neutral language of the statute, many believe that the FMLA actually harms women because it has done nothing to change the leave-taking patterns of men and women. ${ }^{182}$ In other words, if women continue to take parenting leaves for either the birth of a child or to care for a child or parent with a serious health condition, employers will continue to have a disincentive to hire women because employers will view women as more expensive to employ. ${ }^{183}$ Some believe that the main obstacle to equality for women is the reluctance of men to share in caregiving tasks, ${ }^{184}$ and the FMLA did not correct that problem. ${ }^{185}$ As Professor Grossman aptly stated: "no one ever called the law a victory for equality." 186 And the FMLA has also not been a victory for those with caregiving responsibilities. ${ }^{187}$

Because current law has proven inadequate in remedying the disadvantages and discrimination faced by caregivers, reform is needed

180. Smith, supra note 41, at 1444; see also Gershuny, supra note 52, at 201 (noting that the FMLA provides no leave for colds, flu, and pinkeye); Kessler, supra note 6, at 424 (noting all of the routine illnesses not covered by the FMLA, including the common cold, the flu, earaches, upset stomachs, minor ulcers, headaches, and routine dental or orthodontal problems).

181. Kessler, supra note 6, at 429. As Kessler stated:

But women's typical caregiving responsibilities, i.e., caring for young but healthy children or elderly but not seriously ill parents; dealing with minor family illnesses; cooking and cleaning; transporting children or parents to routine medical appointments; and coping with unexpected family emergencies - all the work that women disproportionately and invisibly perform with the family — does not even register as a blip on the radar screen of the American legal system.

Id.

182. See, e.g., Grossman, supra note 125, at 18 (stating that the FMLA "promotes motherhood without promoting equal parenthood").

183. Id. at 27, 47, 49; see also Ariel Meysam Ayanna, Aggressive Parental Leave Incentivizing: A Statutory Proposal Toward Gender Equalization in the Workplace, 9 U. PA. J. LAB. \& EMP. L. 293, 297 (2007) (discussing costs employers anticipate when employing women); Dixon, supra note 13 , at 591 (same).

184. See, e.g., Grossman, supra note 125 , at 40 (stating that the statutory structure of the FMLA "does not account for the main obstacle to equality for working mothers - the reluctance of men to share caretaking tasks and draw on available leave to do so"); Selmi, supra note 19, at 595 (stating that although "men have access to leave [and] are not likely to suffer greater penalties than women for taking that leave... women continue to have overwhelming responsibility for life outside the workplace").

185. See Grossman, supra note 125, at 58 ("Leave-taking data both before and after the FMLA was enacted shows that even after the removal of the state barriers to equality obstacles and even after imposition of statutory guarantees of job security, inequality persists.").

186. Id. at 51 .

187. See Arnow-Richman, supra note 26, at 357 (stating that the FMLA has been criticized for failing to address women's caregiving needs). 
and the reform must be comprehensive enough to protect all working caregivers. Before the reform can be accomplished, however, we need to find a theoretical anchor to justify such comprehensive coverageprotection of real, not just ideal, workers. Part IV will accomplish this next step.

\section{USING COMMUNITARIAN THEORY TO JUSTIFY COMPREHENSIVE REFORM}

As discussed above, the caregiver conundrum manifests itself in many ways, including: the struggle caregivers face when they try to balance work and family and continually find that something suffers, the discrimination in the workplace experienced by many caregivers when their parenting or other caregiving responsibilities make it difficult for them to perform as ideal workers, and discrimination against those who do perform as ideal workers, but are hindered by decisions based on stereotypes that presume otherwise. ${ }^{188}$ Parents and other caregivers should be respected and supported regardless of the decisions they make in balancing work and family. ${ }^{189}$ Some families will choose that one parent, usually the woman, does not work outside of the home. ${ }^{190}$ Some families need both parents, or a single parent, to work full-time and sometimes overtime and yet struggle with unpaid leaves of absence for childbirth or the illnesses of their children. In some families, the mother wants or needs to work, or both, but prefers to have more time with her family than the typical full-time, face-time workplace norm will allow. Finally, some caregivers are forced into their caregiving roles because of the sudden illness, injury, or disability of a loved one. Scholars have debated whether we should focus on achieving more balance for

188. See supra Part II.

189. This statement is obviously overbroad. I do not support a parent's decision to completely neglect their children because of work responsibilities. Young children should not be left alone and should be cared for and taken to the doctor (or hospital if necessary) when sick. Other than serious neglect, however, I believe parents should be able to decide how they want to balance work and family and I support measures that will make more options possible. See infra notes 334-36 and accompanying text.

190. I will admit to some ambivalence about this choice. If a woman or a man makes a completely free choice to remain at home with children - a choice that is not constrained by social forces, pressure from a spouse, or the impression that it is impossible to successfully balance work and family, then I respect that choice. It is my belief that some, but certainly not the majority, of stay-at-home moms have made such a free choice. Even in these cases, however, the stay-at-home parent will have a working spouse, and it is still the case that the spouse might feel the caregiver conundrum when he or she wants to spend more time with his or her children than most workplaces will allow. 
caregivers or trying to get women to work more. ${ }^{191}$ Scholars in favor of the latter approach believe that women will only achieve equality in the workplace if they work like men typically do, i.e., meeting the full-time, face-time norm. ${ }^{192}$ Because I believe that we do not have to choose between these two goals, I do not take sides in the debate. We can support the choices of all caregivers (within reason, of course) and still achieve equality in the workplace. We just need a change in perspective. This part provides that perspective.

In order to support all of the choices of all caregivers, we need to define the caregiver conundrum broadly, to include real workers and not just ideal workers. In other words, when we define which employer practices operate to disadvantage caregivers in the workplace, we need to include those workplace policies and norms that make it difficult for real caregivers to succeed in the workplace. What does this mean in practice? Certainly, this Article does not suggest that coworkers should offer to do caregivers' jobs, either at work or at home. Furthermore, this Article does not suggest that caregivers should be able to work whenever or how much they choose without having any employment consequences. ${ }^{193}$ Instead, this Article suggests that we should support informal attempts by employers, as well as formal law reform, aimed at lessening the burden of the caregiver conundrum. All employees, employers, ${ }^{194}$ and society should support legislation that would provide

191. See sources cited supra note 26 .

192. See generally Dixon, supra note 13; Lester, supra note 20; Selmi, supra note 19.

193. See Selmi, supra note 19, at 576 (criticizing scholars who seem to be arguing that women should be able to do whatever they want with respect to balancing work and family without any penalty).

194. It might seem odd to suggest that employers should support efforts that will require them to change their workplace policies. However, there is a wealth of scholarship demonstrating the financial benefits, in terms of decreased attrition and improved morale, of giving employees the tools necessary to balance work and family. See EEOC CAREgIVER GUIDANCE, supra note 12, at 7-8 (noting that there are benefits to employers in offering workplace flexibility); Williams \& Segal, supra note 19, at 79; see also WILLIAMS, UNBENDING GENDER, supra note 4. One recent study by the Families \& Work Institute found that employees in more flexible and effective workplaces were more likely to have greater engagement, higher levels of satisfaction, more loyalty, and less negative behavior. GALINSKY ET AL., supra note 46, at 3. In other words, flexible workplaces were beneficial to employers and employees. The study also indicated that employers who offer generous caregiving leaves have less difficulty finding and hiring employees who are honest, reliable and hard-working self-starters. Id . at 7. But see Selmi, supra note 19, at 582-85 (disagreeing in part with the idea that family-friendly policies are beneficial to employers). Selmi points out that there has not been enough good data to prove that having a family-friendly workplace benefits employers. $I d$. at 583. He argues that employers might rightfully be concerned with an adverse selection problem, where too many employees who need flexible schedules or other benefits are attracted to a small number of employers who offer them, making them much less feasible. Id. at 582. Other possible reasons employers might not adopt flexible workplace policies, despite their apparent benefits, are concerns over cost or ambivalence about more women in the workplace. Id. at 585; see 
for paid leave or national daycare, or tax credits for employers willing to provide family-friendly workplaces, to name a few examples. ${ }^{195}$ And when an employer voluntarily assumes obligations to provide benefits that enable caregivers to better balance work and family, coworkers should support such measures instead of sabotaging them. ${ }^{196}$

This Article is not the first to suggest that workplace reform should target the policies and norms that disadvantage caregivers who are not meeting the ideal-worker norm. ${ }^{197}$ But why have those previous attempts been unsuccessful? The answer lies in the theoretical underpinnings of current law and prior proposals. ${ }^{198}$ There are two primary attacks that are likely to be levied against a proposal to include real workers when fashioning a remedy for the caregiver conundrum. The first response to the problems faced by caregivers who are not ideal workers is one that places the blame on the "choices" the parent has made. ${ }^{199}$ Many employers, policy makers, and even some scholars, believe that our laws should only protect those who are performing as ideal workers and are being discriminated against despite their ideal-worker habits. ${ }^{200}$ The

also Arnow-Richman, supra note 26, at 380 (discussing reasons employers do not voluntarily accommodate employees' caregiving needs).

195. For a discussion of all of the potential reforms see infra Part V.

196. I recognize that some employers could take this idea too far and allow all caregivers to work a reduced-hour schedule without hiring any additional employees, thereby putting an undue burden on the non-caregiving employees. I personally believe that everyone has a right to balance in their lives, and smart employers will not reserve scheduling benefits for parents. Professor Williams has also argued that employers should make reduced-hour schedules available to all employees, as long as they can present a viable plan for getting the job done, and as long as they are willing to take the reduced pay that goes along with the reduced schedule. WILLIAMS, UNBENDING GENDER, supra note 4, at 86-88. My experience anecdotally tells me that many non-parent employees claim to want a reduced-hour schedule but when push comes to shove, they are not willing to take the pay cut. See also Selmi, supra note 19, at 579 (stating that while many men express an interest in trading salary for less time, they rarely do so); Selmi \& Cahn, supra note 25, at 12 (stating that few employees are willing to trade less income for more time). But see Nancy Rankin, Phoebe Taubman \& Yolanda Wu, Seeking a Just Balance: Law Students Weigh In on Work and Family, A BeTTER BALANCE 3 (June 2008) (surveying law students who overwhelmingly said they were willing to trade money for time in order to balance law practice with a family).

197. See generally Williams, UnBENDING GENDER, supra note 4; Martha Albertson Fineman, Cracking the Foundational Myth: Independence, Autonomy, and Self-Sufficiency, 8 AM. U. J. GENDER SOC. POL'Y \& L. 13 (2000).

198. I am not the first to suggest that current theoretical frameworks do not adequately address the discrimination that occurs for those engaged in caregiving tasks. For instance, Professor Kessler exposes the theoretical flaws that contribute to the law's inability to address what she refers to as "cultural caregiving" - the caregiving that is not biologically based. Kessler, supra note 6, at 43044. She states that "our law's foundational tenets of autonomy, equality, and rationality will be revisited here to make a specific argument about the law's inability to recognize women's cultural caregiving." Id. at 434.

199. WILLIAMS, UNBENDING GENDER, supra note 4, at 6; Selmi, supra note 19, at 589.

200. See generally EEOC CAREGIVER GUIDANCE, supra note 12; Selmi, supra note 19, at 58182. 
rationale of these commentators is that women who choose to have children and choose to not be ideal workers are choosing to not be similarly situated to their non-parent counterparts and therefore deserve to be treated differently. ${ }^{201}$ Moreover, some believe that these employees should be responsible for their choices, rather than passing the burden onto other workers, to employers, or to the public at large. ${ }^{202}$ The second criticism against a proposal to protect real workers is a concern over special-treatment stigma. Scholars have spent quite some time disagreeing with one another about the appropriateness of providing any special benefits or accommodations ${ }^{203}$ to working mothers. ${ }^{204}$ Specialtreatment stigma occurs when employers have an incentive to hire fewer women or other employees who are perceived to or do need special accommodations in the workplace. ${ }^{205}$ The stigma also manifests itself in the resentment of other employees who do not receive any special treatment. ${ }^{206}$ As will be discussed below, neither of these criticisms are adequately addressed by commonly used theoretical frameworks. Accordingly, we need a new theoretical response to these criticisms. Communitarian theory provides that response.

201. See Selmi, supra note 19, at 574-75 (discussing the view that women are choosing to drop out of workforce rather than being forced to leave). Professor Kessler highlights the Law and Economics movement's "rational choice theory" as being to blame for this line of thinking. Kessler, supra note 6 , at $441-42$.

202. See Arnow-Richman, supra note 26, at 374-75 (noting that public assistance is viewed as charity and is therefore stigmatized). Professor Arnow-Richman states: "[c]onsistent with the ideology of the industrial age, it was thought that every able-bodied (and implicitly male) person should be capable of providing for himself." Id. For further discussion see Martha Albertson Fineman, Contract and Care, 76 CHI.-KENT L. REV. 1403, 1421 (2001) (stating that many think a family's need to resort to collective resources rather than caring for themselves is considered a failure and deserving of condemnation and stigma).

203. Another example of employees who need special accommodations in the workplace is individuals with disabilities. Because the Americans with Disabilities Act requires employers to provide reasonable accommodations in the workplace, employers sometimes refuse to hire employees who might need accommodations because of the real or perceived cost in providing those accommodations. See Arnow-Richman, supra note 26, at 363-67 (discussing the ADA's lack of success in challenging workplace norms)

204. See, e.g., Williams \& Bornstein, supra note 4, at 173 (criticizing the accommodation model). For a discussion of the equal-treatment versus special-treatment debate, see infra Part IV.B.1.

205. Francine D. Blau \& Ronald G. EhrenBerg, Introduction, in Gender and Family ISSUES IN THE WORKPLACE 4 (Francine D. Blau \& Ronald G. Ehrenberg eds., 1997) (arguing that mandated leave policies increase costs to employers, which may lead them to pay women less or to not hire as many women to avoid the leave costs altogether); Grossman, supra note 125, at 47-49 (discussing concerns that the FMLA would hurt women because mandated leave would make employers less willing to hire women).

206. See Arnow-Richman, supra note 26, at 392-93; Lester, supra note 20, at 43-44. 


\section{A. The Myth of the Caregiving Choice}

\section{The Rhetoric of Choice}

As stated above, caregiving has not been adequately supported and protected in the workplace because many believe that parenting is a freely-made choice, and thus should be treated accordingly. ${ }^{207}$ Certainly, liberal theory takes this view. Liberal theory emphasizes that we are all discrete, autonomous individuals, and the only job of the state is to keep people from intruding on one another's liberty interests. ${ }^{208}$ Under liberal theory, the ways in which we are connected to each other become secondarily important to liberty. ${ }^{209}$ Attachments and obligations do not matter. ${ }^{210}$ Under this view, both the decision to have children, and the decision about how to balance work and family, are unconstrained choices made by parents. Because the parent has the choice, the parent alone is responsible for the choice, and the market or the state should have nothing to do with the parent's choice. ${ }^{211}$ As long as liberal theory defines parenthood and caregiving as a choice, the law allows employers to treat those who "choose" to become parents differently. ${ }^{212}$

Similarly, Law \& Economics" "rational choice theory" emphasizes the choices parents and other caregivers make. ${ }^{213}$ Simply stated, rational choice theory posits that all humans are motivated by self interest and therefore, if a person engages in an action, it must be in her self interest. ${ }^{214}$ Accordingly, "[v]iewed through the lens of rational choice theory, women's cultural caregiving is a mere choice, for which the state owes no support and employers owe no accommodation." 215

Feminist legal theorists generally dispute the emphasis on autonomy and rational choice, recognizing that many decisions made by mothers

207. Kessler, supra note 6, at 375 ("[T] he influence of rational choice theory ... [has] served to construct women's caregiving as a freely chosen endeavor that is undeserving of protection from discrimination within the workplace.").

208. Maxine Eichner, Square Peg in a Round Hole: Parenting Policies and Liberal Theory, 59 Оніо ST. L.J. 133, 150-51 (1998).

209. Id. at $151-52$.

210. Id. at 152; see also Fineman, supra note 197, at 14 (stating that the "implications of the fact that individuals exist in family or relational contexts are largely ignored").

211. See generally Fineman, supra note 197 (describing and critiquing this view of family).

212. Cf. Kessler, supra note 6, at 441-42 (explaining human choice under rational choice theory and that one's choice to become a parent is owed no accommodation by the employer).

213. Id. at 441 .

214. Id.

215. Id. at 442 . 
are not freely-made, unconstrained choices. ${ }^{216}$ For instance, Professor Martha Fineman questions whether it is fair to consider a woman's choice in becoming a mother a fair choice. Professor Fineman asks: when a woman chooses to become a mother, does this mean that she has consented to "the societal conditions attendant to that role and the many ways in which that status will negatively affect her economic prospects?"217 Furthermore, as some feminists have argued, you cannot separate parents from their attachment to their children. Their parenthood is not just a choice-it is a responsibility and most parents define themselves at least in part by their role as parents. ${ }^{218}$ The responsibility of parenthood removes it from the rubric of a purely voluntary choice. While deciding in the first instance to have children may be a voluntary choice, raising them well is not-it is a responsibility. As one scholar aptly stated:

Engaging in parenting responsibilities is ... different from one's choice of chocolate ice cream over vanilla; the latter is a choice based on taste, the former is a moral imperative based on one's understanding of one's self (conceived of in terms of one's relationships), which stands independent of individual preferences.

However, despite this greater understanding of the autonomy myth, many feminists do not adequately address the caregiver conundrum because they do not consider all of the interests at stake. ${ }^{220}$ Specifically, their focus is more often on women's equality in the workplace, rather than the value of children and raising them well. ${ }^{221}$ The feminist legal theory literature also has not given adequate attention to women in other caregiving roles. $^{222}$ Communitarian theory, on the other hand, does respond to the rhetoric of choice.

216. Id. at 445. Professor Kessler discloses two feminist responses to the rhetoric of choice. Id. The first response is "that women are neither autonomous nor rational decision makers, because biological forces dictate the inevitability of their role as nurturers." Id. The second and prevailing response, however, is "that women are neither autonomous nor rational decision makers, because gender socialization greatly influences their decisions to take on caregiving responsibilities." Id.

217. Fineman, supra note 202 , at 1420

218. Eichner, supra note 208, at 153,171.

219. Id. at 171-72.

220. See Kessler, supra note 6, at 377 (asserting that feminist responses have proven to be less capable of addressing the rhetoric of choice that legitimates discrimination against caregivers).

221. Eichner, supra note 208, at 165.

222. But see Kessler, supra note 6 (examining the law's inability to recognize women's caregiving). 


\section{Communitarian's Response to the Rhetoric of Choice}

Communitarianism is a "set of ideas centered on issues of community, moral education and shared values." 223 It rests on the idea that we have a mutual responsibility to each other as citizens and that a stable political community depends on this shared responsibility. ${ }^{224}$ Relatedly, the absence of Americans' sense of obligation to one another has been criticized: "It is as if we roam at large in a land of strangers, where we presumptively have no obligation towards others except to avoid the active infliction of harm." 225 The contemporary communitarian movement began in 1990 when Amitai Etzioni and William Galston met with a group of ethicists, social philosophers, and social scientists to discuss the matters that "afflict our society,"226 including the troubling nature of Americans who are quick to demand rights but reluctant to accept responsibilities. ${ }^{227}$ The communitarian agenda asserts that it is dedicated to the betterment of our moral, social, and political environment. $^{228}$ Communitarians believe that a community is a place where people really care about one another. ${ }^{229}$

Communitarianism is thought to be opposed to liberalism, with the latter's focus on autonomy and individual rights. ${ }^{230}$ Consider this description of the difference between liberalism and communitarianism:

223. Wendy Brown-Scott, The Communitarian State: Lawlessness or Law Reform for AfricanAmericans?, 107 HARV. L. REV. 1209, 1210 (1994).

224. Id.

225. David Abraham, Are Rights the Right Thing? Individual Rights, Communitarian Purposes and America's Problems, 25 CONN. L. REV. 947, 956 (1993) (reviewing MARY ANN GLENDON, Rights TALK: The IMPOVERISHMENT OF POLitical Discourse (1991)) (using the example of there being no duty under the law to rescue a stranger).

226. Amitai Etzioni, The SpiRit of Community: Rights, Responsibilities, AND the COMMUNITARIAN AGENDA 14-15 (1993).

227. Id. at 15 .

228. $I d$. at 2 .

229. Id. at 31 .

230. Brown-Scott, supra note 223, at 1217 (referring to communitarianism as a "postmodern rejection of liberalism"); see also id. at 1216 (noting that legal and political theorists have critiqued liberalism which has resulted in gain to a small, all-white, all-male community). But see Barbara Bennett Woodhouse, "It All Depends on What You Mean by Home": Toward a Communitarian Theory of the "Nontraditional" Family, 1996 UTAH L. REV. 569, 586 (1996) (arguing that communitarianism does not necessarily conflict with liberalism and that a communitarian perspective does not need to reject personal privacy and individual autonomy). Perhaps somewhere in the middle, communitarianism has also been defined as a "sociological perspective focused on balancing personal autonomy and rights with the common good and shared interests." Nancy Kubasek \& Melissa Hinds, The Communitarian Case Against Prosecutions for Prenatal Drug Abuse, 22 WOMEN's RTS. L. REP. 1, 2 (2000). These authors believe that communitarianism is equally concerned with the collective benefit and personal autonomy-in that it values both individual rights and social responsibilities. $I d$. at 12. 
For the liberal, liberty and autonomy are the only means by which a person incurs an obligation. By contrast, communitarianism maintains that one's most important obligations derive from membership in a community, and cannot be explained by the autonomy model.

Perhaps most importantly for this Article's purpose, communitarians believe that one of the most important communities to which we belong is our families. Communitarians have very strong views about the importance and role of the family. ${ }^{232}$ They believe that we all learn moral values through the communities to which we belong. ${ }^{233}$ Humans depend on each other for the formation of their personalities, ${ }^{234}$ therefore, the "highest priority of social policy is to reach young children and provide them with new and better environments, new and better opportunities.", 235 Etzioni states: "Families and communities are the ground-level generators and preservers of values and ethical systems. No society can remain vital or even survive without a reasonable base of shared values. . . They are generated chiefly in the family . ...,236

Another scholar stated that democracy requires certain traits that are dependent on raising children well: "It demands citizens who can subordinate personal preferences to laws and to elected representatives, appreciate the values of freedom and democracy, recognize the legitimacy of the state, and, at least to some extent, rationally weigh options. Adequate child rearing is central to the development of these characteristics." ${ }^{237}$ The problem, according to some communitarians, is that there are not enough families teaching their children right from wrong. ${ }^{238}$

231. Robert Justin Lipkin, Progressivism as Communitarian Democracy, 4 WIDENER L. SYMP. J. 229, 240 (1999) (footnote omitted).

232. See, e.g., Philip Selznick, The Idea of a Communitarian Morality, 75 CAL. L. REV. 445, 450 (1987) ("charity begins at home"). I believe it is possible to learn from these beliefs even without embracing all of them all of the time. In other words, I follow the familiar mantra "take what is useful and throw out the rest." As I address the communitarian platform regarding families, I will also explain where I part company with some communitarian beliefs. When I refer to the communitarian "platform" regarding families, I am referring primarily to the platform proposed by Etzioni. The Responsive Communitarian Platform: Rights and Responsibilities, in ETZIONI, supra note 226, at 251-67. I do not assert that all communitarians would agree with what I describe as the communitarian platform regarding families.

233. See Brown-Scott, supra note 223, at 1211 (stating that we have lost sight of the importance of civic duty and the role of the family, the school, the church, and the community in identifying shared moral values).

234. Selznick, supra note 232, at 447.

235. Id. at 457 (emphasis omitted).

236. ETZIONI, supra note 226, at 31 (quoting JOHN GARDNER, BUILDING COMMUNITY 5 (1991)).

237. Eichner, supra note 208, at 173 (footnotes omitted).

238. ETZIONI, supra note 226, at 29. It is true that Etzioni defines family traditionally, i.e., 
Etzioni states that parents have a moral responsibility to the community to invest themselves in the proper upbringing of their children. ${ }^{239}$ He believes that there is a parenting deficit in society today, which he blames on both parents working too much and spending too little time at home. ${ }^{240} \mathrm{He}$ believes that children need attention and that both parents should be involved in their children's lives. ${ }^{241}$ Although Etzioni recognizes exceptions for those who must work full-time for economic reasons, he generally believes that strangers should not be raising infants and toddlers, ${ }^{242}$ and that most daycares are understaffed and poor substitutes for parents. ${ }^{243}$

Etzioni also criticizes parents for putting the pursuit of wealth ahead of raising children. ${ }^{244}$ While he recognizes that "women are obviously entitled to all the same rights men are, including the pursuit of greed,"245 he states that "few people who advocated equal rights for women favored

husband, wife, and kids. I do not believe that only traditional families can be successful. But I do agree with communitarians that families of all kinds are not doing a very good job of teaching their children right from wrong. Barbara Bennett Woodhouse argues that we can support non-traditional families while remaining true to a communitarian perspective. See generally Woodhouse, supra note 230. She states:

We must clarify the link between responsibilities and rights without ostracizing households and kin groups that function as "kinships of responsibility" simply because they deviate from traditional nuclear family norms. Rather than distrusting all nontraditional families as antifamily or narrowly individualistic, we need to judge them by what they do.

Id. at 587 .

239. ETZIONI, supra note 226, at 54. This is true even if people are caring for children that they did not necessarily choose to have. See Selznick, supra note 232, at 451 (stating that "[p] arents are responsible for the children they have, not for those they might have liked to have or only for those they choose to have").

240. ETZIONI, supra note 226, at 55-56.

241. Id. at 56 .

242. Id. at 60; see also 29 U.S.C. § 2601(a)(2) (2006) ("[I]t is important for the development of children and the family unit that fathers and mothers be able to participate in early childrearing ....').

243. ETZIONI, supra note 226, at 58, 60.

244. Id. at 63 . He also criticizes parents for getting divorces, arguing that children are almost always better off with an intact family and that changes to the family through divorce are very disruptive to the children. Id . at 60-61. I do not disagree that divorce is a traumatic experience for all of the parties, but I would never assume to know what is best for individual couples and families. This is one of the areas where I disagree with Etzioni, but I do not believe that this disagreement means that we cannot benefit from other aspects of the communitarian platform. For a contrary view on the definition of family, see Woodhouse, supra note 230, at 575 (discussing whether and how non-traditional families can claim legal authority and public support to carry out their caregiving functions). Woodhouse argues that a household is a home "when its members are bound together by a powerful sense of specific obligation-legal, cultural, religious and/or moral." Id. at 576. Woodhouse does not believe that non-traditional families will destroy family values. Id. at 579 .

245. EtZIONI, supra note 226, at 63. But see Kessler, supra note 6, at 384 (noting that most women must work, including married women, whose income is necessary to provide for the family and help them avoid poverty upon divorce). 
a society in which sexual equality would mean a society in which all adults would act like men, who in the past were relatively inattentive to children." "246 While many (including this author) would not agree that all or even most parents are neglecting their parenting duties, it is clear that the full-time, face-time norm of most workplaces makes it difficult for parents to attend properly to the upbringing of their children.

Other scholars have also emphasized the "fundamental morality" of caregiving work and the "importance of such work to the sustenance of society." 247 Professor Kessler states that we need to continually focus on the morality of caregiving "because caregiving work is fundamental to the functioning of society, the continuation of the human race, and the living of a full life." 248 Another scholar stated that it is important to support parenting "because of the important role that fostering connections generally and parenting specifically should play in a healthy community." 249

Understanding the importance of caregiving - not just for the parents who raise the children, but for the rest of society-helps us understand how the focus on the "choices" parents make is flawed. As communitarian theory teaches us, parenting and other caregiving is not simply a choice - it is a responsibility, and caregivers fulfillment of that responsibility benefits everyone. Recognizing this fact provides the response to both the apathy of employers and coworkers. In response to the "why care" question-why care about the choices parents have made? - communitarian theory answers: because raising children well is not merely a choice, it is a responsibility.

Similarly, a caregiver's "choice" to tend to the care of an adult family member who is elderly, sick or disabled is also a responsibility. In many ways, one can view the decision to care for adult family members as even less of a "free choice" than the decision to have children. We do not get to choose our parents, nor do we choose when parents, spouses or other family members become ill or otherwise need care. The only "choice" that might be made in this regard is the choice regarding who in a family is going to care for the ill or disabled family member. In many families, there is no choice. One spouse must care for the other. As families become smaller and more spread out geographically, there are fewer choices regarding who will care for an elderly parent. Instead, in many cases, the only question is how the

246. ETZIONI, supra note 226, at 63.

247. Kessler, supra note 6, at 453.

248. Id. at 456-57.

249. Eichner, supra note 208, at 169 . 
caregiver will balance the caregiving role with her job. Even if a caregiver has the financial resources available to have full-time in-home care or to place the relative in a nursing home, there will still be some caregiving responsibilities. Moreover, many individuals do not have the option of having full-time care for a loved one. They cannot afford such care. Accordingly, caregiving for other adults can also be seen as a responsibility and not merely a choice.

\section{B. Special-Treatment Stigma}

The other criticism likely to be directed at efforts to remedy caregiver discrimination is that the reforms needed to remedy the caregiver conundrum for real workers might cause special-treatment stigma. As mentioned above, this stigma manifests itself in two ways. First, if legal reform required employers to offer accommodations or other special treatment to caregiving employees, ${ }^{250}$ employers might be less likely to hire caregivers, and because most primary caregivers are women, employers might be less likely to hire women. ${ }^{251}$ The second manifestation of special-treatment stigma is in the form of resentment by other employees. $^{252}$ These days, non-parents appear to be even more resentful of parents. ${ }^{253}$ If employers do allow parents to have flex-time, work reduced hours, or to avoid overtime - all measures that might be needed for real workers - the non-parent employees may resent the caregiving employees. This conflict and resentment makes it difficult to justify reform efforts designed to remedy the caregiver conundrum. Adopting reform that would protect all caregivers and not just parents would be one small step in the right direction, particularly because any

250. While it is not this Article's goal to engage in a comprehensive discussion of reform, it seems obvious that at least some of the reform efforts would include forcing or encouraging employers to offer some benefits to caregivers, such as flexible schedules or reduced-hours. Even if the employer offered similar benefits to non-caregiving employees, it would likely be the case that mostly caregivers would take advantage of such benefits, thereby contributing to the specialtreatment stigma.

251. BLAU \& EHRENBERG, supra note 205, at 4 (arguing that mandated leave policies increase costs to employers, which may lead them to pay women less or to not hire as many women to avoid the leave costs altogether); Finley, supra note 123, at 1151; Grossman, supra note 125, at 47-49 (discussing the concerns that the FMLA would hurt women because mandated leave would make employers less willing to hire women).

252. Arnow-Richman, supra note 26, at 392-93; Lester, supra note 20, at 43-44.

253. Arnow-Richman, supra note 26, at 374 (stating that today's workplace creates an environment where the tensions between ideal workers and those with caregiving needs is exacerbated). But see GALINSKY ET AL., supra note 46, at 33 (noting that only one percent of employers mention coworker resentment as an obstacle to providing family-friendly benefits despite the fact that the media mentions this resentment quite a bit). 
employee could find herself in a caregiving role for a family member at any time and therefore should be supportive of such reform. ${ }^{254}$ However, this step is not enough. While more and more adults will find themselves caring for elderly parents or other family members at some point in their lives, the overwhelming majority of caregivers for elders are still women and the number of parents greatly outnumbers those engaging in other caregiving responsibilities. ${ }^{255}$ Accordingly, many scholars have expressed concern over laws and policies that are seen as giving special treatment to women. ${ }^{256}$ Because, as discussed below, this concern has not been adequately addressed by either liberal theory or feminist legal theory, a turn to communitarian theory is warranted.

\section{The Equal-Treatment Versus Special-Treatment Debate}

In addition to liberal theory's emphasis on autonomy and the choices parents make, the other problem with liberal theory is its focus on formal equality or the equal-treatment doctrine - the idea that likes should be treated alike. ${ }^{257}$ Of course, the problem with the doctrine is not the concept of equality itself - after all, who can quarrel with the idea that similarly situated people should be treated the same - rather, the problem is the failure to see differences where they exist and the tendency to treat all differences as inferior. ${ }^{258}$ The equality doctrine is unable to account for differences that are culturally based, which include most of women's caregiving roles. ${ }^{259}$ Because men and women are not similarly situated with respect to caregiving roles, the formal equality principle of liberal theory allows the law, and employers, to treat caregivers differently. ${ }^{260}$

254. See Lester, supra note 20, at 44 (noting that coworkers' objection to providing benefits for caregiving - in this case, paid leave - has less merit when it comes to elder care because people do not choose their parents or plan on them getting sick).

255. Williams, supra note 2 (noting that one in four families care for elderly relatives but also that women are still overwhelmingly the primary caregivers); $c f$. GALINSKY ET AL., supra note 46, at 23 (one study found that seventy-five percent of employers offer time off for employees to care for elders without jeopardizing their jobs).

256. See, e.g., Selmi, supra note 19, at 576 (arguing that women should not necessarily be given many choices of work flexibility, to the extent those choices are not also given to men); Selmi \& Cahn, supra note 25, at 23 (arguing that mandated additional paid leave could cause employers to not hire as many women if employers believed that mostly women would be taking the leave).

257. Littleton, supra note 26, at 1294 (quoting Joseph Tussman \& Jacobus tenBroek, The Equal Protection of the Laws, 37 CAL. L. REV. 341, 344 (1949)) (the hornbook definition of equal protection, which she calls symmetry, is "that those who are similarly situated be similarly treated").

258. Kessler, supra note 6 , at $432,438$.

259. Id. at 434-35.

260. See Finley, supra note 123, at 1153-54 (noting that "our tradition with equality has too often meant prejudice toward those whom the dominant group has labeled as different"). 
Because workplace norms have been set by men considering only their lives and bodies, women's lives and bodies - both the biological fact that they get pregnant and the cultural fact that they do the majority of housework and childcare-will always be seen as different and this difference is then used against them. ${ }^{261}$ Thus, liberal theory's insistence on formal equality means that women's caregiving roles will always be seen as different and therefore justify different treatment. Liberal theory is helpful for remedying discrimination against ideal worker caregiversthey are similarly situated to their non-caregiver counterparts and yet are treated differently - but it cannot be used to remedy discriminatory treatment against real workers because they are not similarly situated to their non-caregiver coworkers.

The equal-treatment doctrine was the main impetus behind the early stages of feminist legal theory. ${ }^{262}$ Beginning in the 1980 s, however, "special-treatment" feminists began to recognize the problem with formal equality. Special-treatment feminists generally believe that women need to be given accommodations or preferential treatment in the workplace and elsewhere to make up for the disadvantages suffered because of pregnancy, childbirth, and caregiving responsibilities. ${ }^{263}$ Special treatment has also been called substantive equality, as opposed to formal equality. ${ }^{264}$ Substantive equality advocates note that even if we treat people alike and "[parcel] out goods such as workplace benefits according to egalitarian distributive principles," this might not provide equal results on the other end. ${ }^{265}$ To make people equal, we often need to give out varying amounts of substantive entitlements. However, as noted above, this special treatment may create resentment among fellow

261. Id. at $1154-56$.

262. Martha Chamallas, Introduction to Feminist Legal Theory, 23-25 (1999). Feminist Legal Theory is thought to have proceeded through stages-Professor Chamallas describes them as the Equality Stage of the 1970s, the Difference Stage of the 1980s, and the Diversity Stage of the 1990s and beyond. Id. at 23-30. According to most courts we are still in the Equality Stage. Id. at 23 .

263. Arnow-Richman, supra note 26, at 350 ("Although there is no consensus on the precise remedial efforts needed to address women's disadvantage, a consistent feature of the discussion is the recognition by most participants that some form of workplace accommodation beyond compliance with basic gender discrimination principles is needed to effectuate equal opportunity for caregivers."); Finley, supra note 123, at 1146-47 (summarizing this view); Kessler, supra note 6, at 439 (noting that some feminists argue for accommodation for biologically-based differences); Littleton, supra note 26, at 1295-96 (discussing the varying "asymmetrical" models of sexual equality).

264. See, e.g., Finley, supra note 123, at 1144.

265. Id. 
employees and may cause employers to hire fewer women because of the real or perceived higher costs of providing these entitlements. ${ }^{266}$

Furthermore, special treatment suffers from one of the same flaws as equal treatment: it uses the male norm as a point of comparison. ${ }^{267}$ Because women are different from men with respect to caregiving responsibilities, the equal-treatment doctrine allows them to be treated differently, yet even the special-treatment approach only sees women as different because it compares them to men. ${ }^{268}$ Some scholars have questioned whether the male norm-as an ideal worker relatively disconnected with family life - is normatively right or merely the norm only because those who have had the power to define the norms have always been men. ${ }^{269}$ As stated by one scholar: "[o]ne wonders why those who appreciate the inadequacy of the male norm for accommodating and measuring women adhere to a doctrinal framework that is designed only to compare against the norm, and not to question it." ${ }^{270}$ Regardless of whether women are the same as men or different from men, the problem with both equal treatment and special treatment is that men are the standard, and the standard itself is never questioned.

Moreover, most Americans do not question why difference matters at all. Professor Christine Littleton proposes a model of "equality as acceptance." 271 She argues that the "difference between human beings, whether perceived or real, and whether biologically or socially based, should not be permitted to make a difference in the lived-out equality of those persons." ${ }^{, 72}$ In other words, male and female differences should be "costless relative to each other." "273 Her approach is very appealing, but the reality is that some differences between sexes are not, in fact, costless. We may theorize that they should be costless all we want, but at the end of the day, leaves of absence and accommodations for caregiving have costs, ${ }^{274}$ so we need another theory to support our willingness to impose these costs.

\footnotetext{
266. Id. at 1151.

267. See id. at 1154-56 (discussing the problem with using the male norm when it comes to women's caregiving responsibilities).

268. See id.

269. Id.

270. Id. at 1156 .

271. Littleton, supra note 26 , at 1285.

272. Id. at $1284-85$.

273. Id. at 1285 .

274. Some would argue that even though accommodating caregiving has costs, these costs are outweighed by the benefit of employee morale and less attrition. See sources cited supra note 194.
} 
Moreover, the equal-treatment versus special-treatment debate ignores the other interests at stake. Feminist legal theory generally does not pay any more attention to the value of children and raising them well than liberal theory does. ${ }^{275}$ Some feminists care about children quite a bit, ${ }^{276}$ but most feminists are primarily concerned with women's equality and secondarily with the importance of children and family. ${ }^{277}$ Some feminists believed that cultural feminism was the answer to the equaltreatment versus special-treatment debate. ${ }^{278}$ Cultural feminism acknowledged and emphasized the relationship of women to their children $^{279}$ - an emphasis which some believe is necessary to have caregiving properly valued in our society and workplaces. The problem with cultural feminism, however, is that it "risks reaffirming the dichotomies of liberal discourse rather than overthrowing them to move toward a world in which interconnection is the norm for both men and women." 280 Put another way, cultural feminism perpetuates the stereotypical role of mother as primary caregiver, rather than recognizing that both sexes can and should nurture children. ${ }^{281}$ Because liberal theory and feminist legal theory have not led to a solution to specialtreatment stigma, a turn to communitarian theory is in order.

\section{Communitarian Theory's Response to Special-Treatment Stigma}

This Article theorizes that the communitarian theory has two responses to special-treatment stigma. ${ }^{282}$ First, as a general matter, communitarians emphasize a departure from a preoccupation with rights in favor of an emphasis on responsibility toward others. Communitarians believe we have a responsibility to everyone in our community. Second, and more specifically, the emphasis on the societal

275. Eichner, supra note 208, at 165.

276. See Kessler, supra note 6, at 379-81 (analyzing various feminist projects that focus on children and caregiving)

277. See, e.g., Eichner, supra note 208, at 166 (providing a leading feminist's argument that focuses on how women are economically disadvantaged by the poor accommodations of employers, rather than focusing on the impact on children and family).

278. See id. at 167 .

279. Id

280. Id.

281. See Littleton, supra note 26, at 1331 (discussing the problems with stereotypes over cultural differences between the sexes).

282. This is my interpretation of how I think communitarian theorists would respond to this specific issue. I have not seen this issue addressed directly by those who claim to be communitarians. 
value of parents raising their children well can help eliminate specialtreatment stigma.

One central tenet of communitarianism is that our over-emphasis on individual rights has hurt our communities and our society. ${ }^{283}$ Communitarians argue that rights come with responsibilities. ${ }^{284}$ Furthermore, not all responsibilities will lead to immediate benefits. ${ }^{285}$ Other scholars have also emphasized the priority of duty over wants, including claims of right. $^{286}$ Although rights are important, communitarians are not rights-centered. Rights are secondary to duty and responsibility. ${ }^{287}$ Communitarians believe that rights alone do not make a good society. ${ }^{288}$ Instead, they believe our preoccupation with rights has gone too far and that a return to politics and community can help to overcome the problems in America. ${ }^{289}$

Instead of an emphasis on rights, the central value of communitarianism is belonging. ${ }^{290}$ As one scholar stated: "[communitarianism's] central doctrinal feature locates the essence of the human being in her relationship to others and to her community."291 Communitarians' core values entail concern for others and the "commons we share." 292 This does not mean that the self is no longer important:

283. ETZIONI, supra note 226, at 4-14.

284. Id. at 1. For instance, according to communitarians, it is wrong to refuse or avoid jury service while simultaneously demanding the right to be tried by a jury of one's peers. Id. at 10 .

285. For instance, we have a responsibility to take care of the environment, but the benefits we gain from that will not be felt immediately. Id. at 10-11; see also Selznick, supra note 232, at 45152 (stating that some obligations are not reciprocal).

286. See, e.g., Selznick, supra note 232, at 454; see generally MARY ANN GLENDON, Rights TALK: THE IMPOVERISHMENT OF POLITICAL DISCOURSE 77 (1991) (stating that "[b]uried deep in our rights dialect is an unexpressed premise that ... we presumptively have no obligations toward others except to avoid the active infliction of harm").

287. Selznick, supra note 232, at 454.

288. See Abraham, supra note 225, at 950-51, 956 (pointing out that America's emphasis on individual rights has led to an inequality of wealth, an increase in children living in poverty, an environment where sociopaths outnumber strollers on many streets, and infant and black male mortality rates that compare unfavorably with third world countries and noting that those in situations of dependency-mothers, children, the sick, the old, and the poor-are worse off in the United States than in any comparable country).

289. See id. 953 (discussing how the focus on rights produces negative synergy, as every claim for rights produces a counter-claim for rights, resulting in "individual absolutism, group egotism, and the disappearance of social obligation").

290. Selznick, supra note 232, at 454.

291. Brown-Scott, supra note 223, at 1217.

292. ETZIONI, supra note 226, at 10; see also Woodhouse, supra note 230, at 573 (criticizing laws and policies that put individual freedoms over equally important values that bind individuals together, such as commitment and responsibility). 
The communitarian ethic recognizes [the] need [for protection of the self], for communities could not exist without individuals - with a sense of self - to animate them. However, one's identity, one's sense of self is shaped by others in the community. Thus, to claim a protective ownership of our individual identities is to claim ownership of the communities that constitute each of us. ${ }^{293}$

Communitarians believe that the community bears the responsibility of each individual member of the community. ${ }^{294}$ As stated in Etzioni's book: "We adopted the name Communitarian to emphasize that the time has come to attend to our responsibilities to the conditions and elements we all share, to the community." 295

One of the problems with special-treatment stigma is that it pits one group against another, in this case, caregivers against non-caregiversand usually, women against men. Communitarian theory teaches that there are other interests at stake - children, adult loved ones who need some care, and the communities to which they belong. Families need more than a marriage license to raise their families - they need an infrastructure of jobs, housing, public health, schools, and community services to raise healthy children. ${ }^{296}$ Similarly, it has been said that "strong, healthy, and vigorous individuals can develop only within the context of strong, healthy, and vigorous communities."297 Instead of viewing accommodations for parenting as only benefitting the parents, communitarian theory helps us to understand that we all benefit from parents' choice to procreate; after all, society needs procreation to continue and employers need procreation to continue to have employees in the future. ${ }^{298}$ As Professor Fineman states: "caretaking work supplies an important and essential public good. Every society and every institution in society is dependent upon caretaking labor in order to perpetuate and reproduce itself." 299 Accordingly, caretaking labor

\footnotetext{
293. Enrique R. Carrasco, Collective Recognition as a Communitarian Device: Or, Of Course We Want to Be Role Models!, 9 LA RAZA L.J. 81, 101 (1996) (footnotes omitted).

294. Kubasek \& Hinds, supra note 230, at 12.

295. ETZIONI, supra note 226, at 15; see also Abraham, supra note 225, at 956 (claiming that our emphasis on individual autonomy makes collective action - whether as a family, a neighborhood, or a trade union - much more difficult than in Europe); Woodhouse, supra note 230, at 585 (discussing the "soft" communitarian perspective that stresses the need to foster communities of mutual responsibility and support).

296. Woodhouse, supra note 230 , at 580

297. Kubasek \& Hinds, supra note 230, at 12.

298. Finley, supra note 123, at 1137-38.

299. Fineman, supra note 202, at 1406.
} 
creates a societal debt, which binds each and every member of society, not only individual family members. ${ }^{300}$

Furthermore, one of the most important lessons learned from communitarianism is that everyone lives with the consequences of children who are not brought up well and who then terrorize communities through misconduct and crime. ${ }^{301}$ Studies indicate that those children who spent too much time taking care of themselves were more likely to engage in risky behavior, such as abusing controlled substances, and more likely to have anger management problems. ${ }^{302}$ Etzioni believes that many of today's problems are attributable to lack of parenting. He states: "Gang warfare in the streets, massive drug abuse, a poorly committed work force, and a strong sense of entitlement and weak sense of responsibility are, to a large extent, the product of poor parenting." 303 Communitarian Mary Ann Glendon agrees. She argues that current patterns of family behavior are not optimal for children. ${ }^{304}$ She also notes the mounting evidence of the relationship "between childraising conditions and crime rates, national competitiveness, and the future of the social security system." 305

Professor Fineman believes that workplaces need to be restructured so that the "burdens for dependency" can be redistributed more equitably between family and market. ${ }^{306}$ In Fineman's analysis, this is not "special treatment" but instead is part of the "basic right of accommodation due to all members of society as they engage in society-enhancing or preserving tasks." 307 She recognizes that there is the possibility for those who do not have caregiving responsibilities to fear that they will be exploited. ${ }^{308}$ Her response is to point out that exploitation of caregivers has been the norm - that the labor of caregivers has always been "appropriated for the good of the larger society without compensation or

300. Id. at $1410-11$.

301. ETZIONI, supra note 226, at 54, 69 ("The community - that is, all of us-suffers the ill effects of absentee parenting.").

302. Id. at 69; see also Dowd, supra note 18, at 449-54 (discussing the negative effects of teenagers being left alone without parental involvement); Kaminer, supra note 9, at 317 (noting that the American work system undermines the needs of children).

303. ETZIONI, supra note 226, at 69.

304. GLENDON, supra note 225 , at 127 (pointing to a study which indicated that "a whole generation of American teenagers was 'less healthy, less cared for and less prepared for life than their parents were at the same age'").

305. Id.

306. Fineman, supra note 202, at 1437 .

307. Id.

308. Id. at 1438 . 
accommodation." 309 Similarly, Etzioni states: "the time has come for both parents to revalue children and for the community to support and recognize their efforts." 310

Accordingly, the communitarian theory supports the effort here to define the caregiver conundrum broadly to include real workers. If we recognize that raising children well takes more commitment from parents than an ideal-worker schedule will allow, ${ }^{311}$ and that raising children well benefits society, we should be willing to help caregivers balance work and family. ${ }^{312}$ Put another way, we should respect and protect real workers and not just ideal workers. Generally, it is real workers who attempt to spend sufficient time with their children to raise them well, ${ }^{313}$ "provid[ing] not only material necessities, but also moral education and character formation." 314 Etzioni believes that "[r]eevaluating the value of children will help bring about the needed change of heart" to support efforts to help parents successfully raise their children. ${ }^{315}$ He states: "Above all, what we need is a change in orientation by both parents and workplaces. Child rearing is important, valuable work, work that must be honored rather than denigrated by both parents and the community." 316 Because parents need workplace flexibility, employers and - to a lesser extent - coworkers should be willing to provide this support so that parents are able to take on the important responsibilities of raising their children and attending to their other caregiving roles. ${ }^{317}$

309. Id.

310. ETZIONI, supra note 226, at 63; see also Selmi \& Cahn, supra note 25, at 25 (discussing the public's responsibility toward raising future generations).

311. WILLIAMS, UNBENDING GENDER, supra note 4, at 53.

312. See Dixon, supra note 13 , at 648 (stating that society as a whole benefits when children are better prepared to contribute as productive members of society).

313. I do not mean to suggest that employees performing as ideal workers cannot be good and influential parents. Many manage to be both ideal workers and great parents, either because they work different shifts, leaving one parent home with the children as much as possible, or because their jobs are not that demanding, making it possible to perform as ideal workers and ideal parents. Sometimes the parents have enough high quality caregiving and household help that they can devote all of their time at home to their children, rather than dividing the time off work between caregiving and other household responsibilities. Having said this, I believe it is easier to be a better parent the more time you have to spend with your children. If I did not have a job that allowed me to do a substantial portion of my work at home, after the kids are in bed, I do not feel that I could be the type of parent I want to be, or that I believe my kids need. Many "ideal workers" are expected to work overtime, and if they have a commute, they often get to see their younger children for only an hour or less each day. I believe that it is difficult to be a good parent-especially to young childrenwhen you only have one hour with your kids each day.

314. ETZIONI, supra note 226, at 256.

315. Id. at 72 .

316. Id. at 257.

317. See supra text accompanying note 194. 
Obviously, coworkers cannot directly provide support to caregivers, but they can avoid sabotaging the efforts made by employers to accommodate working caregivers. ${ }^{318}$ In addition to the most compelling reason for coworkers to support caregivers' efforts - that is, the benefit to society when parents are given the tools to successfully raise their children-there are two other reasons why non-caregiving coworkers should care about the caregiver conundrum. First, flexibility and benefits given to caregivers often have positive spillover effects for noncaregivers. $^{319}$ As I have argued elsewhere, employees should be willing to support each other because the "loyalty given to that community [the workplace] also benefits them." 320 Second, non-parents could find themselves engaging in caregiving at any point. Even if they do not "choose" to have children, they do not get to choose their parents, and many of these parents could become dependent as they age, forcing their children into caregiving roles. ${ }^{321}$ Not only could many workers find themselves engaging in caregiving without affirmatively making the choice to do so, ${ }^{322}$ but fulfilling this role does benefit society. Perhaps the benefit to society of caring for adults is not quite as compelling as the benefits of caring for children. Nevertheless, there are benefits to society when disabled or elderly adults are being cared for by loved ones. Most would agree, and studies show, that people have better health and increased happiness when cared for by loved ones. ${ }^{323}$ Furthermore, society needs the thirty-three million unpaid family caregivers to continue giving that care. ${ }^{324}$ The long-term care system would collapse without the work of unpaid family caregivers, causing nursing homes to

318. See supra text accompanying note 194 .

319. See Travis, Recapturing the Transformative Potential, supra note 11, at 88 (suggesting that successful disparate impact discrimination cases can have spillover benefits to other employees); see also Michelle A. Travis, Lashing Back at the ADA Backlash: How the Americans with Disabilities Act Benefits Americans Without Disabilities, 76 TENN. L. REV. 311, 349-56 (2009) (explaining how benefits given to disabled employees have positive spillover effects for individuals without disabilities)

320. Nicole B. Porter, Reasonable Burdens: Resolving the Conflict Between Disabled Employees and Their Coworkers, 34 FLA. ST. U. L. REV. 313, 361 (2007).

321. Fineman, supra note 202, at 1439. I have made a similar argument with respect to disabilities. See id. at 361-62 (discussing the communitarian theory as a justification for some of the burdens reasonable accommodations provided to disabled employees have on non-disabled coworkers).

322. See supra Part IV.A.2.

323. K. Nicole Harms, Note, Caring for Mom \& Dad: The Importance of Family-Provided Eldercare and the Positive Implications of California's Paid Family Leave Law, 10 WM. \& MARY J. WOMEN \& L. 69, 83-85 (2003) (discussing the benefit of having elders cared for by family members).

324. Jane Gross, Blog, Who Cares for the Caregivers?, N.Y. TIMES, http://newoldage.blogs. nytimes.com/2008/10/14/who-cares-for-the-caregivers/ (Oct. 14, 2008, 9:30 EST) 
"burst at the seams." 325 Finally, we all benefit from allowing caregivers to balance work and family because this means that as we age or become disabled and need care, we will reap the benefits of having institutional structures in place that will allow our loved ones to care for us without sacrificing their jobs.

Etzioni also points out how the benefit of raising children well can impute to employers, who should in turn help caregivers balance work and family. ${ }^{326}$ He explains that what corporations complain about with regard to their employees "is a deficiency of character and an inability to control impulses, defer gratification, and commit to the task at hand." 327 If parents are with their children more to teach them the values to overcome these deficiencies in character, these children will become more productive adult employees. This, in turn, benefits employers, so employers should be willing to invest in their own future by investing in the parents who raise the children of the future. ${ }^{328}$ Etzioni states:

[W]orkplaces should provide maximum flexible opportunities to parents to preserve an important part of their time and energy, of their life, to attend to their educational-moral duties, for the sake of the next generation, its civic and moral character, and its capacity to contribute economically and socially to the commonweal. ${ }^{32}$

I recognize that getting employers and employees to recognize these benefits will require a significant change in attitude. As Fineman noted, most employers "do not consider themselves appropriately held responsible for meeting workers' needs or desires." ${ }^{330}$ I also am not naïve enough to believe that this change in heart will happen

325. Id.

326. ETZIONI, supra note 226, at 67-68; see also Eichner, supra note 208, at 168 (stating that we need to look at all of the interests at stake in the conflict between work and parenting, including the social value of parenting and the necessity of parenting for any community to sustain itself).

327. ETZIONI, supra note 226, at 67.

328. See Finley, supra note 123, at 1175 (stating that "employers should bear [some of the costs of accommodating caregiving] because childbearing and rearing are crucially important social functions that are connected to and have major impacts on the work world"). It would seem that not many employers subscribe to the view that they can benefit from investing in the workforce of the future by investing in the parents who are raising those future workers. One study of employers revealed that only one percent of employers implement work versus life balance initiatives to ensure the workforce of tomorrow is of high quality. GALINSKY ET AL., supra note 46, at 32. Note, however, that this study also indicated that employers do have some benevolent motives for initiating family friendly policies. $I d$. (noting that $7 \%$ of employers studied implement these policies because "it's the right thing to do," $6 \%$ do so because the company considers itself a caring organization, and $4 \%$ do so because the company considers itself a family organization).

329. ETZIONI, supra note 226, at 257 (emphasis omitted).

330. Fineman, supra note 202, at 1434 
immediately or easily. In this sense, I am only beginning a discussion that must continue for some time before we can expect to see any real change. Ultimately, any legal reform in this area should be accompanied by a very good public relations campaign to convince individuals (both employees and employers) why it is to their benefit to support the efforts of caregivers trying to successfully balance work and family responsibilities. $^{331}$

In sum, one does not have to believe in the entire communitarian platform to recognize that the theory provides valuable insight into how we as a society should support caregivers' efforts to balance work and family. If we want the children of today to be successful, productive, law-abiding citizens in the future, we must invest in the upbringing of those children. Similarly, we must recognize the benefits of caring for other adult family members. We all can and should contribute to the solution by defining the caregiver conundrum broadly to include the protection of real workers, not just ideal workers, and we should embrace efforts to remedy discrimination for all caregivers. ${ }^{332}$ Etzioni stated it best:

Having a child is not merely a personal, private matter. It is an act that has significant consequences for the community. Hence those who bring children in the world have a social obligation to attend to their moral education.... The community should enable parents to do this - by encouraging paid leave, flextime, and other such measuresand express its support for such an ordering of priorities. This is not an indirect way of suggesting that mothers should stay home; both parents share the responsibility to attend to their children. The community should not stigmatize but appreciate those who do.

One final caveat: While I believe there is a good deal of merit to the communitarian's emphasis on the importance of raising children well, we should not try to define the substantive contours of what it means to be a

331. In some ways, this issue resembles issues concerning our environment. For a long time, the reaction to environmental advocacy was one of apathy. People could not seem to make changes when there was no immediate benefit. Furthermore, there seemed to be a sense that one person's or even one family's actions could not make a big difference. Recently, however, the public seems to have come together - to some extent - to support environmental efforts. Society now seems willing to make changes even when they will not be the beneficiary of those changes. There is a recognition that the changes are necessary to make the world a better place for future generations. Similarly, helping parents raise their children well will make the world a better place in the future. We simply need to convince employers and employees that supporting parents now is important for our future.

332. See Kaminer, supra note 9, at 322-23. While the communitarian emphasis is on the importance of raising children well, there is also societal benefit to other caregivers providing care to adult loved ones.

333. ETZIONI, supra note 226 , at 88 . 
good parent. We can adopt legal reforms that support parenting without mandating what parents should do. ${ }^{334}$ This point might be controversial. There are some who may argue that if we embrace the communitarian theory and its emphasis on raising children well and we ask employers, coworkers, and society to support measures aimed at helping caregivers balance work and family, then society should have some say on what parents should be doing to raise their children well. This is a valid concern, but we do not need to mandate a certain level and quality of parenting to address it. First of all, the purpose of helping caregivers balance work and family is to increase the range of choices working caregivers have, not to decrease those options. Even if options were available that allowed working parents to work fewer hours, not all caregivers would choose to take advantage of such measures and we should not force them to do so. Studies vary on how much time spent parenting is optimal and many couples who work demanding careers have family members or responsible, loving, nannies caring for their children. Even though there are some who would disagree with a couple's decision to have both spouses meeting the ideal-worker norm, as long as these parents are providing for the care of their children, it is not our place to dictate how these parents choose to balance work and family. ${ }^{335}$

But with that said, if caregivers do choose to take advantage of some accommodations or benefits offered to them, it is a valid argument that these caregivers should actually use these benefits to engage in caregiving tasks. This is not mandating how caregivers parent; it is simply ensuring that they are not abusing benefits given to them. This issue arises under the FMLA and the law has had no trouble dealing with this kind of abuse. Just as an employer can fire an employee who takes an FMLA leave of absence because of a serious health condition but is then spotted out on the golf course, an employer should be able to discipline or terminate an employee who uses an employer's provided leave of absence or reduced-hour schedule for working a second job or

334. See Eichner, supra note 208, at 176 (noting that parents should be able to parent as they see fit and recognizing that what it means to be a good parent varies enormously within and between cultures and over time).

335. It is also important to remember that families come in all shapes and sizes, and a grandparent, aunt, or loving nanny can fulfill many parenting obligations. For a view on an alternative definition of family, see Woodhouse, supra note 230, at 575-76. Woodhouse argues that a household is a home "when its members are bound together by a powerful sense of specific obligation-legal, cultural, religious and/or moral." Id. at 576. Woodhouse does not believe that non-traditional families will destroy family values. Id. at 579. 
pursuing a hobby. ${ }^{336}$ In sum, while we should not mandate the exact contours of how a caregiver chooses to parent-meaning we should let ideal workers continue to be ideal workers-we can control for and handle the abuse that might occur under any law reform mandates that require an employer to provide flexibility to its caregiving employees.

\section{Ending the "Maternal Wall",337}

While this Article is devoted to all caregivers, both men and women, and both parents and other caregivers, the fact is that the difficulties of the caregiver conundrum flow mostly to women with children. ${ }^{338}$ It is this Article's primary argument that we should define the caregiver conundrum broadly to include real workers because of the importance to society of raising children. But I also am motivated by the desire to eliminate the rampant disadvantages that flow to women because of the caregiver conundrum. The costs of discrimination against caregivers is high: "The economic and social subordination of women that flows from the history of workplace incompatibility with their childbearing role has contributed to the economically and psychologically damaging phenomenon known as the feminization of poverty."339 We are beyond the time when modern employers can operate without women, ${ }^{340}$ yet many of the traditional workplace norms operate to push women out. ${ }^{341}$ It is not enough that we have laws that account for biological differences between the sexes; we also must consider social differences between the sexes. $^{342}$ In reality, women still perform the majority of childcare and housework tasks. ${ }^{343}$ Laws and employer policies that harm caregivers

336. An employer can certainly choose to offer reduced hours and flexible schedules for other reasons besides caregiving responsibilities and some argue that they should. WILLIAMS, UNENDING GENDER, supra note 4, at 85-88. However, if they only offer such benefits for caregiving and the employee is not using it for caregiving, then the employer should be able to discipline the employee.

337. Id. at $69-70$

338. See generally id. (arguing that market and family organization are the cause of caregiver issues, especially with regard to women with children); Kessler, supra note 6 (showing a lack of legal protection for women caregivers with children).

339. Finley, supra note 123, at 1176. Discrimination against caregivers also harms children, increasing their poverty and leading to increased child abuse. Gershuny, supra note 52, at 213-14.

340. Dixon, supra note 13, at 649 ("It is by now clear that the American economy will probably never again function without the work of women."); Kaminer, supra note 9, at 323 (explaining that working parents are valuable employees).

341. See Williams, UnBending Gender, supra note 4, at 85 (questioning whether the conflicting social norms of the ideal worker and of parental care can be reconciled).

342. See Williams \& Segal, supra note 19, at 80 (arguing that workplaces should not be designed around a man's body and a man's traditional immunity from caregiving).

343. See Williams, UnBending Gender, supra note 4, at 1, 50 ("[I]n one-half to one-third of 
levy a disproportionate harm on women. In other words, remedying the caregiver conundrum for all workers will assure both workplace equality for women and the well-being of future generations. ${ }^{344}$

In response to some critics who, echoing the resentment of coworkers, wonder why parenthood and caregiving deserves special treatment, it is important to remember that there are many other social programs and policies that force employers to spend money in a way that benefits some, but not all, employees. ${ }^{345}$ Examples include unemployment, workers' compensation, and perhaps the best example, military leave. ${ }^{346}$ Military leave provides an apt analogy because, although some women need it, it mostly applies to men, and the law requires employers to reinstate employees who have been on military leave for up to five years. ${ }^{347}$ Those in the military are provided this "special treatment" because they are engaging in what many believe is socially desirable behavior. ${ }^{348}$ So are caregivers. The fact that most caregivers are women, and that our current system operates to discriminate against them, is simply another reason for protecting caregivers. However, the primary reason for protecting caregivers is, and should be, that they are engaging in socially desirable behaviorraising the next generation of citizens and taking good care of their loved ones.

\section{WHERE WE GO FROM HERE}

If communitarian theory provides the justification for protecting real workers, the question remains: how do we best go about fashioning reform in this area? It is not the goal of this Article to engage in a comprehensive discussion of all of the reforms needed and how they should be implemented. That is a discussion left for the next Article. Instead, this part will give an overview of what might be required to remedy the caregiver conundrum. This part will first give a general overview of the types of reforms that have been suggested, many of

families, mothers are at home.").

344. See Lester, supra note 20, at 18 (arguing that paid family leave matters not only for gender equality, but also because it can improve child and elder welfare).

345. See Arnow-Richman, supra note 26, at 379 (comparing caregiving benefits as a logical outgrowth of other types of benefit packages).

346. Finley, supra note 123, at 1175-76.

347. Uniformed Services Employment and Reemployment Rights Act of 1994, 38 U.S.C. § 4312(a) (2006); see also id. at 1176 ("[D]efending the country in military service... is a task performed almost exclusively by men.").

348. See Finley, supra note 123, at 1175-76. 
which will be necessary to remedy the caregiver conundrum. This part will then use the example of one specific reform, and discuss how the communitarian theoretical framework would justify it. Finally, this part will respond to two anticipated criticisms of this Article's proposal.

\section{A. A Laundry List of Reforms}

This Article has focused on the theoretical justification for broad reform, whereas the eventual goal of the reform piece will be to ameliorate the disadvantages faced by all caregivers. ${ }^{349}$ Reform must consider not just highly compensated professional women, but also lower-income laborers; ${ }^{350}$ not just full-time employees, but also part-time employees; not just women who want to work fewer hours, but also women who financially need to work full-time and overtime; not just pregnant women, but women after their babies are born and before they leave for college; not just ideal workers, but real workers. Comprehensive reform would also mean protecting caregiving employees regardless of the choices they make in balancing work and family. ${ }^{351}$ In other words, whether a caregiving employee needs more time, ${ }^{352}$ or needs more financial support in the form of subsidized daycare or paid time off, reform should be aimed at helping all caregivers successfully balance family and work.

The list of possible reforms is almost endless: amend Title VII to add "parental or family status" to the list of protected categories; ${ }^{353}$ amend the FMLA or enact a new statute to cover more routine childcare needs, such as doctor's appointments, visits with teachers, and minor illnesses; ${ }^{354}$ reduce the workweek; ${ }^{355}$ amend the FMLA to cover more

349. See Dowd, supra note 18, at 434 (arguing that all classes and races need to be included in the discussion of work versus family policy).

350. Recently, several scholars have emphasized the need for reform to include low-income workers. See generally id.; O'Leary, supra note 52; Selmi \& Cahn, supra note 25, at 8.

351. But see Selmi, supra note 19, at 576 (arguing that the work versus family "debate has stalemated because of a desire to support all choices for women"). I both agree and disagree with Selmi's position. I agree that caregivers should not be able to work wherever and whenever they choose without financial penalty. But I disagree with Selmi's position that workplace equality for women - which he believes requires women to work more-is more important than workplace flexibility, which allows women and men caregivers to be better parents.

352. See supra Part II.A.

353. But see generally Smith, supra note 26 (exploring but ultimately rejecting this as a viable solution).

354. See id. at 618; Arnow-Richman, supra note 26, at 399; Kessler, supra note 6, at 462-63. During his campaign, President Obama promised to expand the FMLA to include absences for "elder care needs," as well as up to twenty-four hours of leave each year to participate in children's academic activities at school. See BarackObama.com, Strengthening Families and Communities, 
employees by decreasing or eliminating the one year or 1,250 hours of work requirement or decreasing the number of employees required to trigger coverage, or both; ${ }^{356}$ amend the FMLA, the Pregnancy Discrimination Act, or enact a new statute to provide for paid leave rather than only unpaid leave ${ }^{357}$ provide subsidized daycare or begin the public school system at a younger age, or both, ${ }^{358}$ require or incentivize employers to provide family-friendly workplace policies, such as reduced hours, flexible hours, work from home arrangements, or jobsharing; ${ }^{359}$ enact statutes designed to protect part-time employees; ${ }^{360}$ enact process laws, which require employers to engage in an interactive

http://www.barackobama.com/issues/family/index_campaign.php (last visited Sept. 26, 2009).

355. Barbara R. Bergmann, Work-Family Policies and Equality Between Women and Men, in GENDER \& FAMILY, supra note 205, at 278; Kessler, supra note 6, at 461.

356. For a discussion of the eligibility requirements see supra Part III.C. See also O'Leary, supra note 52, at 59-60. President Obama also plans to expand the FMLA to cover businesses with twenty-five or more employees, rather than the current requirement of fifty. BarackObama.com, supra note 354 .

357. See Lester, supra note 20; O’Leary, supra note 52, at 60; Michael Selmi, Family Leave and the Gender Wage Gap, 78 N.C. L. REV. 707, 770-72 (2000). Etzioni suggests that we should have at least six months of paid leave for new parents and another eighteen months of unpaid leave so that parents can be home for the first two years of the child's life. ETZIONI, supra note 226, at 71. Almost all European countries provide for significantly more paid leave than we do. See Finley, supra note 123, at 1173 (discussing the European countries which almost all provide significantly more leave for childbirth and parenting). Some scholars argue that we should specifically incentivize men to take paternity leave to eliminate the gender imbalance in the workplace caused by the reality that women take far more leave than men. See, e.g., Ayanna, supra note 183, at 296-97.

358. See generally Dixon, supra note 13. Some also suggest that the school day and year should be lengthened to assist lower-income workers with burdens of after-school care. Barbara R. Bergmann, Work-Family Policies and Equality Between Women and Men, in GENDER \& FAMILY, supra note 205, at 278; H. Elizabeth Peters, The Role of Child Care \& Parental Leave Policies in Supporting Family \& Work Activities, in GENDER \& FAMILY, supra note 205, at 280-83; Kessler, supra note 6, at 461; Selmi \& Cahn, supra note 25, at 9.

359. Some have argued that there should be an accommodation model similar to the Americans with Disabilities Act or religious discrimination to protect caregivers need for different schedules in the workplace. See, e.g., Stephen F. Befort, Accommodation at Work: Lessons from the Americans with Disabilities Act and Possibilities for Alleviating the American Worker Time Crunch, 13 CORNEll J.L. \& PUB. POL'Y 615 (2004); Kaminer, supra note 9; Kessler, supra note 6, at 461; Smith, supra note 41. Other scholars suggest that we need to convince employers to provide these policies voluntarily based on the ample literature regarding the long-term financial benefits of doing so. See, e.g., Williams, UNBENDING GENDER, supra note 4, at 86-88; Rachel Arnow-Richman, Public Law and Private Process: Toward an Incentivized Organizational Justice Model of Equal Employment Quality for Caregivers, 2007 UTAH L. REV. 25, 25-28 (2007). Finally, some scholars suggest that we provide tax incentives to those employers who are willing to become a more familyfriendly workplace. See, e.g., ETZIONI, supra note 226, at 70-72. President Obama also favors trying to expand flexible work arrangements. His plan is to create a program to "inform businesses about the benefits of flexible work schedules for productivity and establishing positive workplaces; helping businesses create flexible work opportunities; and increasing federal incentives for telecommuting." BarackObama.com, supra note 354.

360. WILLIAMS, UNBENDING GENDER, supra note 4, at 107-08. 
process regarding requests for workplace flexibility; ${ }^{361}$ strengthen the disparate impact theory of liability under Title VII; ${ }^{362}$ amend unemployment compensation laws to provide for benefits for employees who leave the workforce because of caregiving responsibilities; ${ }^{363}$ and strengthen the power of unions. ${ }^{364}$ While the details of such comprehensive reform are being left for another day, many of the above reforms would need to be included in order to end the caregiver conundrum for all caregivers, regardless of whether those workers need more time or more financial support.

\section{B. One Example: Protection Against Termination}

Even though it is not this Article's purpose to engage in a detailed discussion of all of the reforms necessary to remedy the caregiver conundrum, it is helpful to give some idea of how the communitarian framework would justify at least one reform. This sub-part will provide one example of a reform that would be a necessary part of the entire reform package to remedy the caregiver conundrum and then will describe how the communitarian theory justifies this particular reform.

Some of the most troubling stories of work versus family conflict involve a caregiver having to make the impossible decision between leaving a child alone and losing one's job. ${ }^{365}$ Employees tell heart-

361. See, e.g., Arnow-Richman, supra note 359, at 65 (discussing how traditional lawmaking is unlikely to result in the needed flexibility to create more inclusive work practices); Travis, The FullTime, Face-Time Norm, supra note 11, at 266-67 (discussing the United Kingdom's "right to request law," which allows employees to request workplace flexibility without fear of retaliation and forces employers to respond to the request, denying it for only particular enumerated reasons). In December 2007, the Working Family Flexibility Act was introduced in the Senate, which, if enacted, would give employees the right to request flexible work options to help them balance work and family, without the fear of retaliation by their employers. While the law would not require employers to grant employees' requests, it would require that employers engage in an interactive process and if they deny the request, the employers must explain the grounds for denial. Working Families Flexibility Act, S. 2419, 110th Cong. (2007). I believe these proposals for process rights are great first steps. There is a great deal of benefit to allowing employees to be heard regarding their requests for work and life balance and forcing employers to take these requests seriously. Ultimately, however, I believe we need to move beyond process and toward more substantive rights for caregivers.

362. See, e.g., O'Leary, supra note 52, at 58 (suggesting that the Pregnancy Discrimination Act should be amended to codify the disparate impact theory); Travis, The Full-Time, Face-Time Norm, supra note 11, at 263 (discussing the success of disparate impact litigation in the United Kingdom).

363. Kessler, supra note 6, at 461.

364. Arnow-Richman, supra note 26, at 399, 409-16 (suggesting "revitalizing worker organization" as an important part of accommodating caregivers).

365. Healthy Families Act, S. 910, 110th Cong., § 2(9) (2007) (stating that the "absence of paid sick leave has forced Americans to make untenable choices between needed income on the one hand and caring for their own and their family's health on the other"). 
wrenching stories: losing a job because the employee's child was in a car accident and had to be taken to the emergency room, forcing older children to miss school to stay home and care for young children who are sick, losing a job because the employee stayed home with her child who had the flu, and sending sick kids to school and daycare. ${ }^{366}$ The consequences of leaving children unattended can be even worse than losing one's job. In one example, a mother left her one-year-old and nine-year-old children alone because the babysitter did not arrive and her employer had threatened termination if she did not report to work. ${ }^{367}$ While she was gone, the children died in a fire. ${ }^{368}$ Similarly, in another case, a two-year-old left alone fell from a balcony and died. ${ }^{369}$ These and countless other stories never told make this a prime area to begin the reform discussion. Furthermore, while there are many employment actions that disadvantage caregivers - refusal to hire, lower pay, denied promotions - termination is certainly the most damaging employment decision, ${ }^{370}$ as the workplace equivalent of "capital punishment.",371 Many people have their entire identity wrapped up in their job and occupation. For them, termination means not only a loss of regular paychecks, but also means "dashed expectations as to future benefits, a loss of character and personal identity, and the loss of the financial security one expected." ${ }^{372}$ One scholar has said this about termination:

Dismissal affects a person's economic, emotional, and physical health in ways unparalleled by less drastic forms of discipline or transitory interruptions of work. Not only does dismissal have immediate financial consequences for the discharged worker, it also has an economic impact into the future .... The loss of one's job is felt not

366. 9To5, Nat'L Ass'N OF Working Women, 10 Things That Could HapPen to You IF

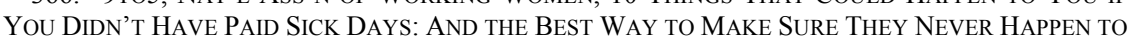
ANYONE, available at http://1000voicesarchive.org/resource/228/10things.pdf (last visited Sept. 23, 2009).

367. Nina Bernstein, Daily Choice Turned Deadly: Children Left on Their Own, N.Y. TIMES, Oct. 19, 2003, at N1.

368. Id.

369. Id.

370. Nicole B. Porter, The Perfect Compromise: Bridging the Gap Between At-Will Employment and Just Cause, 87 NEB. L. REV. 62, 116-17 (2008).

371. Lorraine A. Schmall, Keeping Employer Promises When Relational Incentives No Longer Pertain: "Right Sizing” and Employee Benefits, 68 GEO. WASH. L. REV. 276, 277-78 (2000); Donna E. Young, Racial Releases, Involuntary Separations, and Employment At-Will, 34 LOY. L.A. L. ReV. 351, 352-53 (2001) (citing MARK A. RothSTEIN \& LANCE LiebMan, EMPlOYMENT LAW: CASES AND MATERIALS 910 (4th ed. 1998)).

372. Schmall, supra note 371 , at 278. 
only by the individual worker but by members of his or her family and the community.

Certainly, the caregiver conundrum has far broader consequences than causing the termination of caregiving employees, but the significance of termination renders it a great place to start the reform efforts.

Accordingly, a necessary, but certainly not sufficient, reform would protect employees against termination when they are performing mandatory caregiving tasks. ${ }^{374}$ Certainly, the devil is in the details, and there have been some efforts to define what these mandatory caregiving tasks might include. ${ }^{375}$ At a minimum, employees should be protected when they miss work because they have no responsible person with whom to leave a child under the age of twelve, ${ }^{376}$ despite having made reasonable efforts to find such a responsible person. Such an emergency situation might arise because of the child's illness that precludes the use of home or group-based daycare or school, because an in-home babysitter or nanny is too ill to care for the child or otherwise fails to show up for work, or because the child's school is unexpectedly closed. Certainly there are likely to be disputes regarding what constitutes reasonable efforts to find alternative care arrangements, as well as who is a responsible person. ${ }^{377}$ Furthermore, such a prohibition might need limits on frequency - i.e., how often or how many times an employee should be protected from termination when they have caregiving emergencies. These details are important but are not the focus of this Article. Instead, the focus of this Article is to explain how the communitarian theory justifies this and other reforms. I turn to that now.

373. Young, supra note 371 , at 353.

374. It is, for my current purposes, immaterial where such a prohibition appears. However, it seems to make the most sense that the FMLA would be amended to include a provision that I am suggesting here. However, if that were to be the locus of this prohibition, the coverage of the FMLA would need to be expanded to include all or almost all employees for at least this prohibition.

375. Kaminer, supra note 9, at 340-44.

376. Undoubtedly, this age limit could be debated. I arrived at it rather informally. I have a fifteen-year-old who was so mature that she was babysitting her two little sisters at twelve years of age. I probably would have left her alone at ten years of age if I had the misfortune to be in the position to have to choose between leaving her alone and losing my job. I realize how fortunate I am that I have never been forced to make such a decision. But I also recognize that my daughter was more mature than most children and that many parents would feel uncomfortable leaving a ten or eleven-year-old unattended for an entire day, especially if that child was sick. On the low end, I also have an eight-year-old and I would never consider leaving her alone for even a couple of hours, much less an entire workday. Is there some debate regarding at what age between nine and twelve would be appropriate for leaving a child alone? Certainly, but as stated above, the devil is in the details and this Article cannot solve all of these problems.

377. While those details would need to be fleshed out, as well as establishing documentation requirements, this Article does not and cannot discuss all of these details. 
Both employers and non-caregiving coworkers might resent the law reform presented above. Employers might resent it because such a reform would mean forced modifications to employers' mandatory (and often very strict) attendance policies. Some employers might also argue that such a law would allow for increased absences, ${ }^{378}$ which will decrease productivity and increase costs. Non-caregiving coworkers might argue that such a law unfairly privileges the choices made by parents and that they (the non-caregiving employees) should benefit from having made the decision to not have children. For instance, they might argue that other absences should similarly be protected, such as: absences for an employee's own illness; absences because of unavoidable car trouble or other transportation problems; and absences because of a spouse's or other family member's illness or injury.

How does the communitarian theory respond to these concerns? First, communitarian theory's emphasis on the importance of raising children well and the dangers of leaving children alone demonstrates how important such a reform would be. ${ }^{379}$ It is precisely this type of neglect (leaving children unattended) that can lead to serious consequences, not just for the child and his family, but for all of society. ${ }^{380}$ Because the consequences of leaving children unattended are so serious, parents should not be forced to make a decision between the welfare of their children and financial security. ${ }^{381}$ When parents lose

378. There is a counter-argument to such an allegation. Under current law, if an employee is in a position where the employee's child is sick and the employee is out of absences-assume a nofault absence system, where the employer allows a limited number of absences - the employee would be tempted to find a way to come under the protection of the FMLA, if the employee works for an employer covered by the FMLA and if the employee is eligible for FMLA leave, as indicated by her years of service and hours worked in the past year. See supra Part III.C. To obtain FMLA protection, the employee would need to show that her child had a serious health condition. 29 U.S.C. § 2612(a)(1)(C) (2006). Many children's illnesses do not qualify as a serious health condition either because they are short in duration or they do not require the care of a medical professional. Gershuny, supra note 52, at 203-04; see also $\S 2611(11)$. In these cases, the employee might feel compelled to try to claim that the illness falls under the umbrella of a serious health condition to avoid termination under the attendance policy. If they do so, they might be forced to make a shorter illness last longer in order to fit the definition of serious health condition. Anecdotally, I have seen many employees use, or perhaps abuse, the FMLA in this way and such over-uses or abuses do not benefit anyone. Employees should be protected when they are forced to miss work because of mandatory caregiving responsibilities.

379. See Healthy Families Act S. 910 110th Cong., § 2(15) (2007) (stating that "[it] is in the national interest to ensure that all Americans can care for their own health and the health of their families while prospering at work").

380. As just one example, if a parent sends a sick child to daycare or school because the parent cannot miss work without being terminated, the child is likely to infect other children, which affects other employees.

381. The Healthy Families Act makes a similar point: section 2(9) states that the absence of paid sick days has forced Americans to make untenable choices between needed income and jobs on the 
their jobs, it has negative consequences on the children as well, who may grow up in poverty, and are more likely to suffer from abuse at the hands of their distraught parents. ${ }^{382}$

Second, communitarian theory demonstrates that parenting well is not merely a choice, but a responsibility. ${ }^{383}$ At the very minimum, parenting well includes not leaving a young child unattended for an entire workday. Because refusing to leave a child unattended is a parent's responsibility, not just a parent's choice, parents should be given at least the bare minimum assistance necessary to allow them to meet this very minimal parenting obligation. Understanding parenting as a responsibility rather than a choice responds to concerns of noncaregivers, who might resent the fact that parenting absences are excused when other absences are not. Many of us might agree that other types of absences should be excused, but the difference between the absences that non-caregivers might wish to have excused and absences caused by mandatory caregiving responsibilities is that those involving caregiving do not just affect the employee - they affect the child and the proper upbringing of children is important, not just to the child and his family, but to society as a whole. ${ }^{384}$ Thus, embracing communitarian theory can help to justify this reform, which will in turn help solve the caregiver conundrum.

While the example above is probably one of the most important protections that could be offered to caregivers, it is certainly not sufficient by itself. Only a comprehensive solution will truly solve the caregiver conundrum. Until now, much of the resistance to such comprehensive reform came in the form of apathy (why should we care about the choices made by working caregivers?) and resentment (why should working caregivers get any special benefits for the choices they have made?). However, if we embrace the communitarian lesson regarding the importance of caregiving, hopefully we get beyond apathy and resentment and toward a society that respects "the most difficult job you will ever love."

one hand, and caring for their own and their family's health on the other. S. 910.

382. Gershuny, supra note 52, at 198-99, 213-14 (pointing out how many children live in poverty, and noting that as a parent's income plummets, the parent is more likely to degrade and abuse the children).

383. See supra Part IV.A.2.

384. See supra Part IV.B.2. 


\section{Responding to the Critics-What Reform Will Not Do}

As stated above, this Article does not discuss the details of the eventual reform that will be needed to solve the caregiver conundrum. However, this sub-part will address the two common criticisms that will likely be levied against any proposed reform efforts. The first criticism is that proposals to remedy caregiver discrimination will put too much of a financial burden on employers. Even though employers would not be at a competitive disadvantage with other U.S. employers (because they would all be subject to the same laws), there is a concern that additional employer mandates will put U.S. companies at a competitive disadvantage in the global marketplace. The second criticism is that reform might put too much of a burden on coworkers. I will address each of these criticisms in turn.

It is true that any employer mandate might cost employers money. But many of the needed reforms are relatively inexpensive, and to the extent that they cost money, that cost is often offset by increased employee morale, loyalty and retention. Some of the reforms that would be relatively inexpensive and even result in a net gain to employers (when considering decreased attrition) are measures like flex-time, work from home arrangements, job sharing, part time or reduced hour arrangements (with a requisite reduction in pay and benefits), and process laws, which require employers to engage in a process regarding requests for workplace flexibility. ${ }^{385}$ Some reform measures will impose some costs on employers that might not be offset by decreased attrition, but are not likely to be cost-prohibitive. I am referring here to an expansion of the FMLA to include smaller employers (25 or more employees, rather than 50), or to include some time off for more routine caregiving needs. Because the FMLA only allows for unpaid leave, these measures will not be overly expensive. Certainly, it does cost money for an employer to give even an unpaid leave of absence (and be required to leave the job open for the employee as the FMLA requires) but the cost should not be prohibitive. Most importantly, however, the measures that would likely be considered expensive, such as paid leave, national daycare, longer school days, or other measures that are needed to help lower-income employees, would have to be subsidized and supported by the government. Because all of society benefits from the caregiving tasks performed by working caregivers, the government should be involved in supporting this socially desirable behavior.

385. See supra Part IV.A. 
Turning now to the second criticism, that remedying the caregiver conundrum would put an undue burden on other employees, there are a few responses. First, when this Article proposes that other employees support rather than sabotage reform efforts, this does not mean that noncaregiving coworkers should have to take on the work of the caregiving employees. That is not what reform would do. Some part of the reform might encourage, incentivize or require employers to offer more flexibility to caregiving employees, but that does not mean that employees that get that flexibility get a pass on getting their jobs done. Furthermore, even if employers are meeting some of the needs of caregiving employees, it is unlikely that employers would naturally place extra burdens on coworkers. Analogously, there seems to be a real reluctance to do so in the disability context. For instance, employers are reluctant to infringe on another employee's seniority rights by reassigning an employee with a disability instead of a more senior nondisabled employee. ${ }^{386}$ Finally, to safeguard against this possibility (no matter how remote), any law reform that would give benefits to caregivers should include a provision that can be analogized to the proviso in the Equal Pay Act (EPA) that forbids an employer from complying with the EPA by lowering wages of men. ${ }^{387}$ Here, employers should be forbidden from complying with the legal requirements with regard to caregivers (whatever those might eventually be) by forcing coworkers to pick up the slack.

As stated earlier, this Article does not discuss in detail all of the reform measures that might be required to remedy the caregiver conundrum. Accordingly, there are likely to be additional criticisms to any eventual reform that are not addressed here. However, what should be clear from the above discussion is that reform does not have to lead to overly cumbersome burdens on either employers or non-caregiving coworkers.

\section{CONCLUSION}

Why care about caregivers? We should care about caregivers because they are raising the next generation (or caring for the prior generation), and their success in that endeavor benefits us all. Communitarian theory helps us recognize that we are not just a society of individuals roaming around; we are interconnected in such a way that our

386. See, e.g., U.S. Airways v. Barnett, 535 U.S. 391, 391 (2002).

387. 29 U.S.C. $§ 206$ (d) (2006). The EPA forbids an employer from paying female employees less than its male employees for performing equal work. Id. 
actions affect one another. If we care about our future generations, we must do what we can to help parents raise future generations, and this entails helping caregivers balance work and family. Reform efforts to remedy caregiver discrimination must protect all caregivers, including real workers, not just ideal workers. There are costs to caring. But not caring comes with the biggest cost of all—children (and adults) with caregivers who do not have enough time to care for them. ${ }^{388}$

388. See Kaminer, supra note 9, at 316 (discussing the harm to children if parents are not given workplace accommodations that allow them to adequately care for their children). 